\title{
Towards $\beta$-Selectivity in Functional Estrogen Receptor Antagonists
}

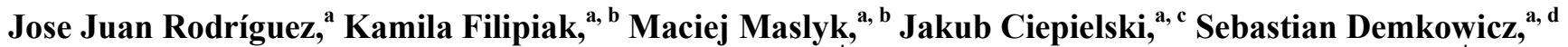 \\ Sonia de Pascual-Teresa, ${ }^{\mathrm{e}}$ Sonsoles Martín-Santamaría, ${ }^{{ }^{*}}$ Beatriz de Pascual-Teresa, ${ }^{a}$ Ana Ramos. ${ }^{{ }^{*}}$
}

\author{
Received (in XXX, XXX) Xth XXXXXXXXX 20XX, Accepted Xth XXXXXXXXX 20XX \\ ${ }_{5}$ DOI: 10.1039/b000000x
}

Based on the benzo $[b]$ naphtho[1,2- $d]$ furan and benzo $[b]$ naphtho[1,2- $d]$ thiophene frameworks, a series of ligands with different basic side chains (BSCs) has been synthesized and pharmacologically evaluated. Also, their binding modes have been modelled using docking techniques. It was found that the introduction of a BSC in these systems brings about a decrease of affinity for both estrogen receptors $\alpha$ and $\beta$ in an in vitro competitive binding assay. However, two full antagonists of the estrogen receptor $\beta$ (9c and 9f) have been 10 discovered, with potency in the low micromolar concentration in a cell-based luciferase reporter assay, and completely devoid of activity against the $\alpha$ receptor at the same concentration range. Differences in the ER $\alpha / E R \beta$ binding modes have also been rationalized with the help of molecular modelling techniques. This interesting functional profile could be used to elucidate the physiological role of each ER subtype.

\section{Introduction}

15 The biological actions of estrogens are manifested through two genetically distinct estrogen receptors (ER $\alpha$ and ER $\beta$ ) that display nonidentical expression patterns in target tissues. Interesting differences have been found in the physiological role of both receptor subtypes. ER $\alpha$ is predominantly involved in the ${ }_{20}$ development and function of the mammary gland and uterus, and in the maintenance of metabolic and skeletal homeostasis. ER $\beta$ has more pronounced effects on the central nervous system and on cellular hyperproliferation. ${ }^{1}$

Since the discovery of ER $\beta$ in 1996, compounds that are selective 25 in activating or inhibiting both ER subtypes are intensively sought after. ${ }^{2}$ The data obtained suggest that the discovery of compounds that selectively bind $\mathrm{ER} \alpha$ or $\mathrm{ER} \beta$ is of great interest for the development of more efficient drugs for the treatment of several disorders, such as cancer, cardiovascular disease, multiple 30 sclerosis and Alzheimer's disease. ${ }^{3,} 4$ The use of the ER $\alpha$ selective agonist propylpyrazoletriol (PPT) (Fig. 1) has shown that several classical estrogen-induced tissue responses can be effectively evoked via ER $\alpha$ alone. ${ }^{5}$ On the other hand, the design of highly ER $\beta$ selective ligands has proved to be quite 35 challenging, and several groups have reported attempts to design this kind of compounds using different scaffolds. The highly ER $\beta$ selective agonist ERB-041 (Fig. 1) has been used to demonstrate that this receptor may be a useful target for certain inflammatory diseases. This compound has a dramatic beneficial effect in the

40 HLA-B27 transgenic model of inflammatory bowel disease and the Lewis rat adjuvant-induced arthritis model, while it is inactive in several classic models of estrogen action. ${ }^{6}$ Other nonsteroidal scaffolds which have been developed as ER $\beta$ ligands are diarylpropanenitriles, ${ }^{7}$ 2-phenylnaphthalenes, ${ }^{8,} 9$ and phenyl-2H45 indazoles. ${ }^{10}$

Interestingly, some substituted tetrahydrochrysene ligands such as $c i s-(R, R)$-diethyl (THC) (Fig. 1) have been described as potent This journal is (C) The Royal Society of Chemistry [year] agonists on $\mathrm{ER} \alpha$, but more potent antagonists on $\mathrm{ER} \beta,{ }^{11,12}$ in<smiles>[Z17]O[R5]#P</smiles><smiles>CCC1Cc2cc(O)ccc2C2=C1c1ccc(O)cc1C[C@H](C(F)F)C2</smiles>

$\mathrm{THC}$<smiles>CC/C(=C(\c1ccccc1)c1ccc(OCCN(C)C)cc1)c1ccccc1</smiles>

Tamoxifen
Pyrazolo[1,5-a]pyrimidines

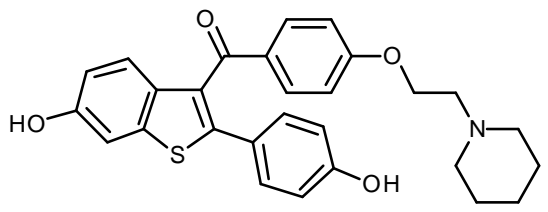

Raloxifene
Fig.1 Chemical structures of some known ER $\alpha$ - or ER $\beta$-selective ligands and tamoxifen and raloxifene.

contrast with tamoxifen and raloxifene which are partial antagonists on both ER $\alpha$ and ER $\beta$ (Fig. 1). The structure of these ${ }_{55} \mathrm{ER} \beta$ antagonists is also different from the structure of tamoxifen 
and raloxifene, where the bulky basic side chain (BSC) is responsible for their antagonist activity through the blockage of the ER helix-12 movement by an interaction with Asp351 carboxylate (ER $\alpha$ numbering) ${ }^{13}$ Crystallographic structures of 5 the ER $\alpha$ ligand binding domain (LBD) bound to both THC and a fragment of the transcriptional coactivator GRIP1, and ER $\beta$ LBD bound to THC show that this compound antagonizes ER $\beta$ through a novel mechanism termed "passive antagonism". ${ }^{14}$ Other series of ER $\beta$-selective modulators based on a 1,3,510 triazine scaffold, that behave as ER $\alpha$ partial agonists and ER $\beta$ antagonists, have been identified. ${ }^{15}$

However, there are few examples of compounds that are more potent antagonists of ER $\beta$ than of ER $\alpha .^{2}$ Pyrazolo[1,5a]pyrimidines (Fig 1) possess this new profile: they are passive 15 on both ERs, with a distinct potency selectivity in favor of ER $\beta$. In a recent structure-based virtual screening, one antagonist for both subtypes, showing significant selectivity for ER $\beta$, was discovered, which showed inhibitory activities on the proliferation of MCF-7 cell line. ${ }^{16}$

${ }_{20}$ Compounds acting as ER $\beta$ antagonists are interesting to probe the biology of this receptor subtype, and they can be useful to understand the role that the ER $\beta$ play in several types of cancers such as prostate, colon and lung cancers, where it is the predominant ER subtype. ${ }^{4}$

${ }_{25}$ With the purpose of extending the available scaffolds useful for the design of new selective estrogen receptor modulators (SERMs), we initiated a program directed to the synthesis of tetracyclic systems containing an oxygen or sulphur atom, and an additional cyano substituent, that could be used to introduce the 30 appropriate basic chains (Fig. 2). We found that compounds $\mathbf{2}$ and 3, with a modest selectivity for ER $\beta$ in a scintillation proximity assay, behave as ER $\beta$ agonists and a ER $\alpha$ antagonists, ${ }^{17}$ and present an interesting antitumor activity against two pancreatic cell lines. ${ }^{18}$<smiles>[R]c1ccc2c(c1)-c1cc(C#N)c3cc(O)ccc3c1-2</smiles>

1: $\mathrm{R}=\mathrm{H}, \mathrm{X}=\mathrm{O}$

2: $\mathrm{R}=\mathrm{OH}, \mathrm{X}=\mathrm{O}$

3: $\mathrm{R}=\mathrm{OH}, \mathrm{X}=\mathrm{S}$

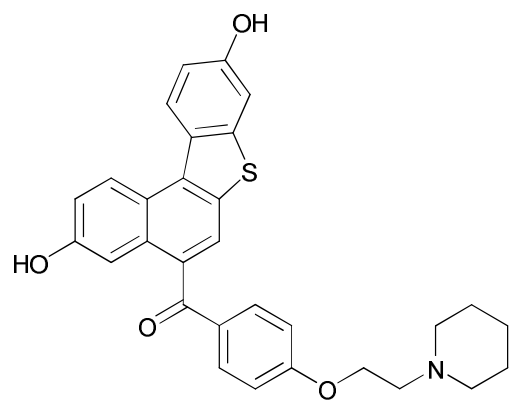

$9 a$
Fig.2 Chemical structures of compounds 1-3 and 9a.

The aim of the present study is to transform these ER $\beta$ agonists into antagonists by the introduction of the BSCs present in tamoxifen, raloxifene and other antagonist described in the 40 literature. We have evaluated the ER $\alpha$ and $\operatorname{ER} \beta$ binding affinities of the synthesized compounds and studied the transcriptional efficacy and MCF-7 antiproliferative activity of the most interesting of these. The most active compounds in the series behave as ER $\beta$-selective functional antagonists, what make them 45 interesting tools to elucidate the biological effects of this receptor subtype. Molecular modelling studies have helped to rationalize these findings.

\section{Results and discussion}

50

\section{Chemistry}

In our previous work we described the synthesis of benzonaphthofurans and naphthothiophenes 1-3, and we studied their affinity towards both estrogen receptors $\alpha$ and $\beta .{ }^{17}$ These 55 compounds were designed bearing a cyano group in their structure to allow their transformation into antagonists by the introduction of the appropriate BSC. In fact, a basic side chain was introduced to give 9a (Table 1) via the five step synthetic pathway depicted in Scheme 1, demonstrating that these are 60 suitable scaffolds for the design of potential new SERMs.

In this paper we have extended this study to the synthesis of compounds 9b-9j (Table 1) following the same synthetic pathway. Thus, compound $\mathbf{5 b}$ was synthesized by reacting $\mathbf{4 b}$ with 4-fluorophenylmagnesium bromide. Treatment of $\mathbf{5 b}$ with ${ }_{65} \mathrm{BBr}_{3}$ gave $\mathbf{6 b}$, which was transformed into the benzyl-protected derivative $\mathbf{7 b}$ by reaction with benzyl bromide in the presence of $\mathrm{K}_{2} \mathrm{CO}_{3}$. Both $7 \mathbf{a}^{17}$ and $7 \mathbf{b}$ were useful intermediates for the synthesis of the final compounds 9, through a nucleophilic aromatic substitution of the fluorine atom by the corresponding 70 alcohol or amine using $\mathrm{NaH}$ and $\mathrm{K}_{2} \mathrm{CO}_{3}$ respectively as a base, followed by deprotection of the hydroxyl groups. Deprotection using $\mathrm{H}_{2}$ and $\mathrm{Pd} / \mathrm{C} 5 \%$ at different conditions of pressure and temperature gave poor yields of the deprotected compound. ${ }^{17}$

However, the use of black palladium and ammonium formiate as 75 the source of hydrogen gave excellent yields of compounds $\mathbf{9}$, which were converted to the corresponding hydrochloride salts to be tested in the biological assays. 


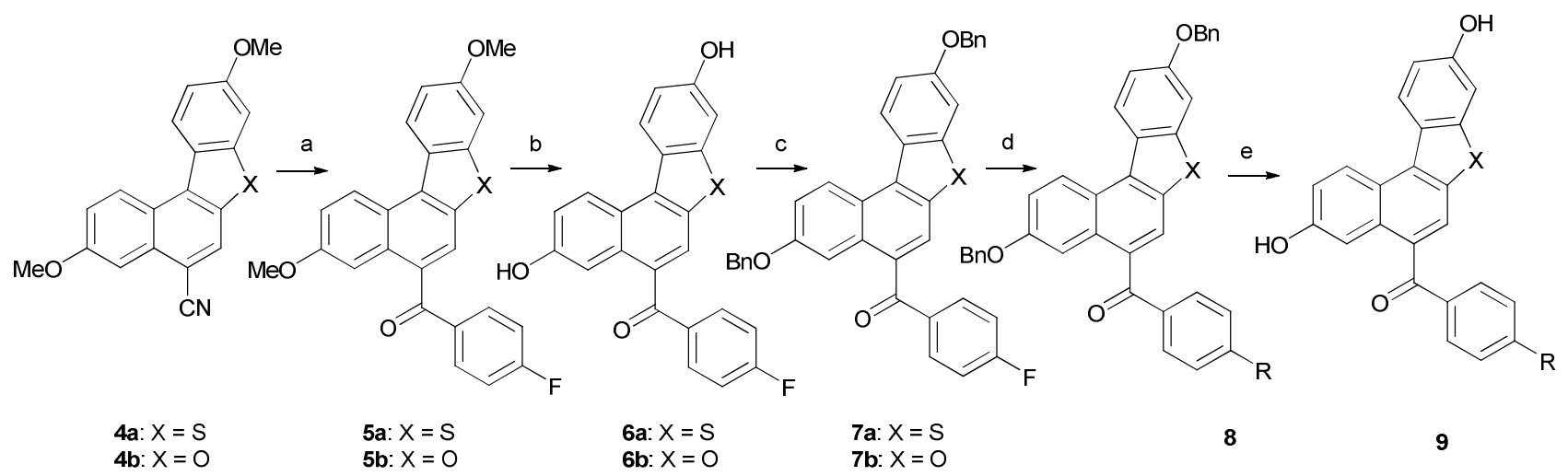

Scheme 1. Reaction conditions for the synthesis of compounds $\mathbf{8}$ and 9. (a) 4-fluorophenylmagnesium bromide, $\mathrm{THF}$ reflux for $24 \mathrm{~h}, 98 \%$ for $\mathbf{5 b}$; (b) BBr 3 , DCM, 95\%; (c) benzyl bromide, $\mathrm{K}_{2} \mathrm{CO}_{3}$, EtOH, 95\% for 6b; (d) RH/NaH, DMF for $\mathbf{8 a - c}$ and 8 f- $\mathbf{h}$ or $\mathrm{RH} / \mathrm{K}_{2} \mathrm{CO}_{3}, \mathrm{DMF}$ for $\mathbf{8 d}, \mathbf{e}$ and $\mathbf{8 i}$,j ; (e) $\mathrm{H}_{2}$, black palladium, ammonium formiate

5 Table 1. Chemical Structure and Yields in the Synthesis of Compounds 8a-j and $9 \mathbf{a}-\mathbf{j}$.

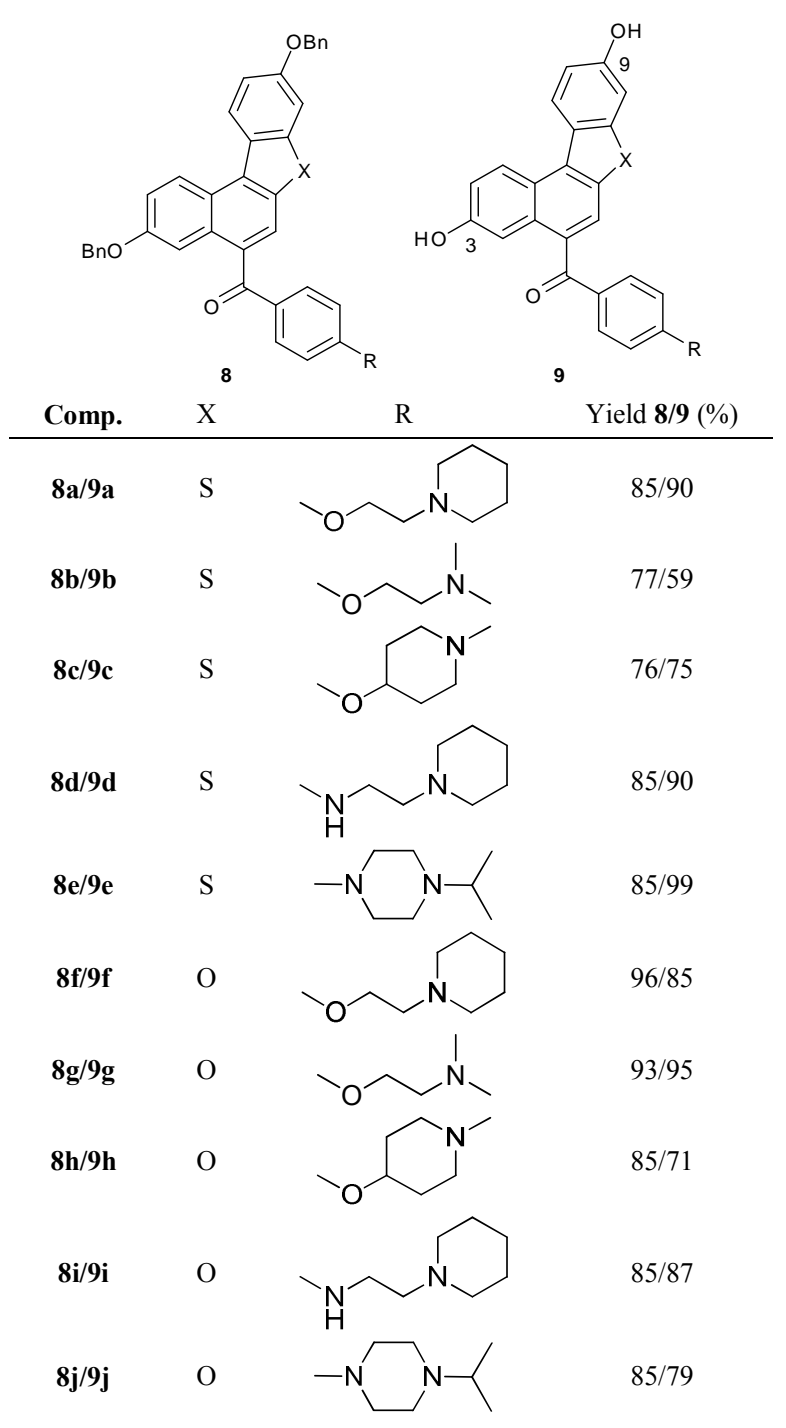

receptor. In order to explore different binding modes of the ER in complex with agonists and antagonists, several crystallographic structures were used: $\mathrm{ER} \alpha$ in complex with estradiol (PDB 15 1A52), raloxifene (PDB 1ERR), genistein (PDB 1X7R) and 4hydroxytamoxifen (PDB 3ERT), and ER $\beta$ in complex with genistein (PDB 1X7J), THC (PDB 1L2J) and 4hydroxytamoxifen (PDB 2FSZ). Two different docking programs were used, AutoDock4 and Glide, to compare the results (see ESI 20 for docking energies).

Although compound $\mathbf{6 b}$, with a short side chain, is a synthetic intermediate, we were also interested in the study of its binding mode, so it was considered in the docking calculations, as well as estradiol, genistein and 4-hydroxytamoxifen as reference 25 compounds to validate the computational protocols. Overall results are here presented; focusing on the different features found in the binding, therefore relevant biological information can be inferred for the series of compounds.

For compound $\mathbf{6 b}$, in general, the results of the docking studies ${ }_{30}$ predicted best binding poses towards ER $\beta$, in terms of docking energy (for example, the value of Glide score was: ER $\alpha=7.6$ $\mathrm{kcal} \mathrm{mol}^{-1} ; \mathrm{ER} \beta=-10.0 \mathrm{kcal} \mathrm{mol}^{-1}$ ) and were in agreement with the experimental data of RBA (relative binding affinity). Hydrogen bonds are established between the HO-9 group with ${ }_{35}$ Arg346 and the carbonyl group of Leu339, between the HO-3 group with Thr299, and between the carbonyl group and the NH of His475 (Fig. 3). The side chain occupies a hydrophobic region delimited by residues Leu380, Ile373 and Phe377. An alternative binding mode is also observed in which the aromatic ring 40 provides a stacking interaction with the imidazole ring of His 475. The docking calculations in ER $\alpha$ predicted a binding mode in which the two hydroxyl groups establish hydrogen bonds with Arg394-Glu353, and with Thr347, while the side chain establishes a stacking interaction with the imidazole from His524. 45 As expected, no binding pose with interactions with ER $\alpha$ Asp351 (ER $\beta$ Asp303) was predicted (Fig. 3).

\section{Molecular Modelling}

Docking studies. Docking studies were performed on selected 10 final compounds (9a-9c and $\mathbf{9 f - 9 j}$, Table 1) with the aim of studying how different BSCs modulate the interaction with the 


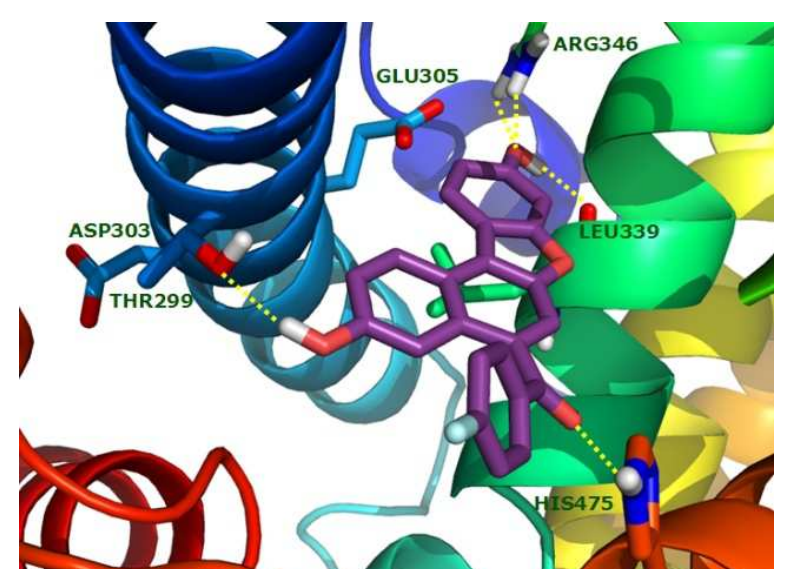

Fig.3 Docked binding mode obtained with Glide for compound $\mathbf{6 b}$ in ER $\beta$.

For compounds $\mathbf{9 a - 9}$ c and $\mathbf{9 f - 9 j}$, docking studies allowed the identification of binding poses in agreement with the obtained 5 affinity values (Table 2), noticing key interactions of the tetracycle into the LBD similar to those for genistein and 4hydroxytamoxifen: hydroxyl groups establish hydrogen bonds with Glu353, Arg394 and/or the Leu387 carbonyl group in one of the binding site ends, and with His524 in the other end (ER $\alpha$ 10 numbering).

Careful study of the results reveals some differences depending on the nature of the tetracycle. For benzothiophene derivatives (9a, 9b and 9c), only docked binding poses into ER $\beta$ showed the characteristic interactions together with one interaction of the

15 BSC with Asp303, putting forward the possibility of an antagonist behaviour. Remarkably, compound 9c clearly showed ER $\beta$ selective antagonism in the functional characterization studies (Table 3).

Regarding benzofuran derivatives, for compounds $9 \mathrm{~g}, \mathbf{9 h}$ and $\mathbf{9 i}$, 20 several binding poses were predicted without remarkable $E R \alpha / E R \beta$ differences in terms of energy, either with AutoDock or Glide. Although in the case of ER $\beta$ a larger number of binding poses was obtained, the theoretical binding energies were very similar, not pointing to a clear prediction of selectivity for these

25 three compounds. However, this was not the case for the other benzofuran compounds, $\mathbf{9 j}$ and $\mathbf{9 f}$. It is worth mentioning that for compound $\mathbf{9 j}$, both docking programs only led to binding solutions in ER $\beta$. For compound 9f only ER $\beta$ binding solutions were predicted by AutoDock, while Glide showed similar results 30 in both receptors (Fig. 4). These results could point towards a theoretical ER $\beta$ selectivity for $\mathbf{9 j}$ and $\mathbf{9 f}$. As it will be shown below, affinity data confirmed these predictions. Moreover, both compounds showed to be ER $\beta$ selective in the functional characterization studies. Additional MD simulations were 35 performed on ER $\beta-9 f$ complex (see below).

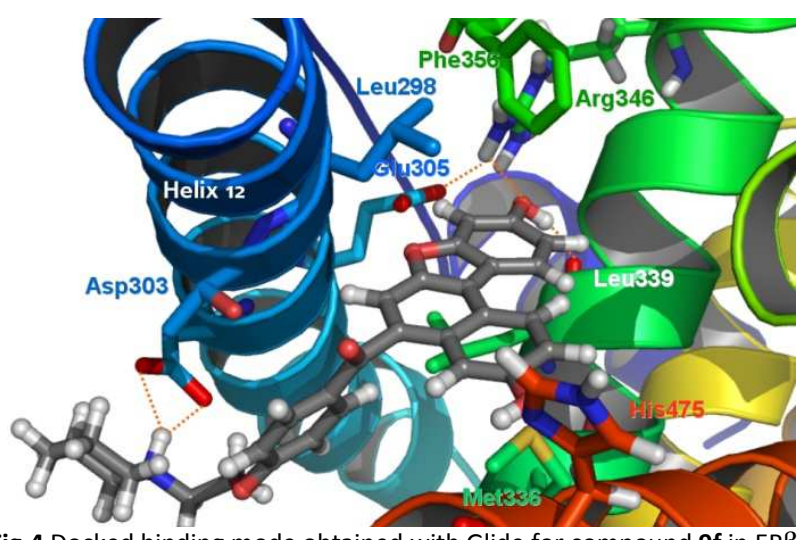

Fig.4 Docked binding mode obtained with Glide for compound 9 f in $E R \beta$.

Superimposition of docked poses of compound 9f and the 40 thioderivative 9a led to the observation of a shift of $9 \mathbf{a}$ relative to the position occupied by $\mathbf{9 f}$ within the LBD, which is justified by a repulsion of the sulphur atom with Ala302 side chain. This shifting also prevents the hydrogen bond formation between $\mathrm{OH}-$ 9 group and Arg346, and might explain the poor ER $\beta$ affinity 45 found for this compound. The larger volume of the thioligand and this repulsion could also justify that the docking studies did not provide any binding solution in the $\mathrm{ER} \alpha$ for compound 9a. A similar repulsive interaction, involving the sulphur atom, was observed in the thioderivative $3,{ }^{17}$ thus accounting for the ER $\beta$ so selectivity. It is worth mentioning that for compounds $9 a, 9 c$ and 9j docking results were only obtained in the ER $\beta$. In the agonism/antagonism profile assays, compound $9 \mathbf{c}$ showed an $\mathrm{IC}_{50}$ value of $0.148 \pm 0.0068 \mu \mathrm{M}$ as $\mathrm{ER} \beta$ antagonist (see below), which is in agreement with the prediction.

${ }_{55}$ Regarding the nature of the side chains, docking studies led to better results for compounds with flexible chains in terms of energy, number of binding poses and geometry of the interaction (data not shown), highlighting the interaction of the protonated BSC nitrogen with the Asp303 carboxylate from helix-12. ${ }_{60}$ However, it is important to mention that this interaction was also observed in scarce solutions for the piperidine derivatives. In any case, the best docking results corresponded to the ER $\beta$ binding.

\section{Molecular Dynamics Simulations.}

${ }_{65}$ Prompted by the experimentally found ER $\beta$ selectivity for compound 9f, molecular dynamics simulations were performed on the ER $\beta-9 f$ complex. The starting structure was obtained from the docking studies (see Experimental). Initially, during the equilibration period, positional restraints to $\alpha$-carbon atoms were 70 applied, together with a distance restraint to keep the interaction between the Asp303 carboxylate moiety and the piperidinium $\mathrm{NH}$ group. Then, restrictions were gradually lowered until no restriction was applied. As a further step, two independent MD simulations were then continued: the first one maintained the ${ }_{75} \mathrm{COO} \cdots \mathrm{HN}$ distance restraint during the initial $500 \mathrm{ps}$ followed by $1 \mathrm{~ns}$ of simulation with no restriction, while the second one was run without any restrictions during 2 ns. The analysis of the results showed that the complex remained fairly stable during the simulations, maintaining a variety of stabilizing interactions 80 within the LBD. However, in both cases, the above mentioned salt bridge was lost within a few ps when the corresponding 
restriction was removed. Indeed, it was observed that the Asp303 side chain suffers a conformational change, exposing the carboxylate moiety to the solvent (see ESI). Then, it fluctuates during the rest of the simulation time, establishing transient 5 hydrogen bonds with water molecules. In any case, rotation of the helix-12 would be prevented due to the stability of the receptorligand complex, and to the presence of the BSC.

\section{Estrogen Receptor Binding Affinity}

10 The RBAs of compounds $\mathbf{6 b}, 9 \mathbf{a}-\mathbf{c}, 9 \mathbf{9}, \mathbf{9 h}-\mathbf{j}, \mathbf{1 0}$ and $\mathbf{1 1}$ were determined in an in vitro competitive binding assay following a reported method ${ }^{19}$ with some modifications. To compare the affinity of these compounds with their parent tetracyclic analogues lacking the basic chain, we have also measured the

15 RBAs of $\mathbf{2}$ and $\mathbf{3}$ in this assay. Table 2 shows a summary of the results obtained $\left(\mathrm{E}_{2}\right.$ has a RBA of $\left.100 \%\right)$. In these conditions, 2 was found to have the highest RBA for $E R \alpha(0.128)$ and $E R \beta$ (0.39), with a slight selectivity for $\operatorname{ER} \beta(\beta / \alpha=3.05)$, which is in agreement with our previously published affinity results using a 20 scintillation proximity assay. ${ }^{17}$ In the case of the benzonaphthofuran series, compound $\mathbf{3}$ showed less affinity than the oxygen analogue 2, with a RBA of 0.029 for ER $\alpha$ and 0.115 for $E R \beta$, and similar selectivity $(\beta / \alpha=3.05)$. The RBA values for 6b, and 9 vary from 0.013 to 0.120 for $E R \alpha$ and from 0.027 to 250.097 for ER $\beta$, showing that the introduction of a short side chain (compound 6b) or a BSC brings about a decrease on the affinity of this type of compounds and a decrease in selectivity. It should be noted that in our experimental conditions the binding between estradiol and ER $\alpha$ is more effective than that of ER $\beta$. Since data 30 are expressed as percentage related to estradiol this means that the actual ratios ER $\beta / E R \alpha$ may be even higher than calculated.

In our previous work ${ }^{17}$ on ER ligands based on novel tetracyclic scaffolds, the most interesting result was found for compounds 2 and 3, which behaved as ER $\beta$ agonists and ER $\alpha$ antagonists, and 35 presented 3.5-fold higher affinity toward ER $\beta$. This result was rationalized, based on molecular modelling studies, by an additional interaction between the cyano group present in these compounds and ER $\beta$ Thr299, not present in the docked complex with ER $\alpha$. In an attempt to improve the affinity and selectivity of 40 this type of compounds, and to get more information on the importance of this interaction, we carried out docking studies of twelve analogues of $\mathbf{2}$ and $\mathbf{3}$, by substituting the cyano group by functional groups able to establish hydrogen bonds with Thr299.

45 Table 2 Estrogen Receptor Relative Binding Affinity (RBA) and $\mathrm{IC}_{50}$ for Compounds 2, 3, 6b, 9a-h, 10 and 11.

\begin{tabular}{cccccc}
\hline ligand & $\mathrm{ER} \alpha$ & $\mathrm{ER} \beta$ & $\mathrm{RBA}$ & $\mathrm{RBA}$ & $\beta / \alpha$ ratio \\
& $\begin{array}{c}\mathrm{IC}_{50} \mathrm{a} \\
(\mu \mathrm{M})\end{array}$ & $\begin{array}{c}\mathrm{IC}_{50} \mathrm{a} \\
(\mu \mathrm{M})\end{array}$ & $(\mathrm{ER} \alpha)$ & $(\mathrm{ER} \beta)$ & \\
\hline
\end{tabular}

$\begin{array}{cccccc}\mathbf{2} & 7.02 & 1.76 & 0.128 & 0.39 & 3.05 \\ \mathbf{3} & 30.83 & 6.0 & 0.029 & 0.115 & 3.93 \\ \mathbf{6 b} & 68.0 & 25.0 & 0.013 & 0.027 & 2.08 \\ \mathbf{9 a} & >100 & 49.27 & - & 0.013 & - \\ \mathbf{9 b} & 21.40 & 25.29 & 0.042 & 0.027 & 0.65 \\ \mathbf{9 c} & 12.78 & 18.07 & 0.07 & 0.038 & 0.54 \\ \mathbf{9 f} & 24.92 & 12.19 & 0.036 & 0.056 & 1.56 \\ \mathbf{9 h} & 7.46 & 7.38 & 0.120 & 0.093 & 0.77 \\ \mathbf{9 i} & 34.8 & >50 & 0.025 & - & - \\ \mathbf{9 j} & 11.66 & 7.06 & 0.077 & 0.097 & 1.26 \\ \mathbf{1 0} & \mathrm{NA} & \mathrm{NA} & \mathrm{NA} & \mathrm{NA} & - \\ \mathbf{1 1} & 23.91 & 31.59 & 0.037 & 0.021 & 0.56\end{array}$

${ }^{a}$ Values are an average of at least 3 experiments with typical standard errors below 15\%; NA-not achieve binding at the assayed concentration.

${ }_{50}$ These functional groups were: $\mathrm{COOH}, \mathrm{COOCH}_{3}, \mathrm{CONH}_{2}, \mathrm{CHO}$, $\mathrm{COCH}_{3}$, and $\mathrm{CH}_{2} \mathrm{OH}$, and the docking was carried out in both alpha and beta ERs, in agonist (PDB codes 1X7E and 1YYE) and antagonist (PDB codes 1ERR and 1L2J) conformations. Docking results were able to highlight proper interactions with Thr299 in ${ }_{55}$ the antagonist conformation of ER $\beta$, without showing remarkable differences between furan/thiophene analogues. Finally, compounds $\mathbf{1 0}$ and $\mathbf{1 1}$ (Fig. 5) were synthesized to test their biological behaviour. The competitive binding assay showed that the substitution of the cyano group by a carboxylic acid (10) 60 brings about a complete loss of affinity. In the case of ester 11, a decrease on the affinity for ER $\beta$ is observed, while the affinity for $\mathrm{ER} \alpha$ is little affected.<smiles>[R]c1cc2sc3cc(O)ccc3c2c2ccc(O)cc12</smiles>

10: $\mathrm{R}=\mathrm{COOH}$

11: $R=$ COOMe

Fig.5 Chemical structures of compounds 10 and 11.

${ }_{65}$ In vitro Functional Activity of Selected ER ligands.

With the purpose of characterizing the agonist/antagonist profile of these compounds, we have selected compounds $\mathbf{6 b}$ and $\mathbf{9 f}$ as representative ER $\beta$ binders and 9c as a representative ER $\alpha$ binder. The agonistic and antagonistic activities of the 70 compounds were evaluated using a commercially available cellbased assay (INDIGO Bioscience's ER Reporter Assay), which allows quantifying functional activities of the tested compounds, against $\mathrm{ER} \alpha$ and ER $\beta$. The system utilizes non-human mammalian cells engineered to provide constitutive high-level 75 expression of ER $\alpha$ and ER $\beta$. Additionally, these cells contain either ER $\alpha$ or ER $\beta$-responsive luciferase reporter gene. Thus, quantification of luciferase activity provides a surrogate measure of ER $\alpha$ and ER $\beta$ activation in the treated reporter cells. Although the compounds possessed only low RBAs, they proved to have a 80 significant antagonistic effect on ER $\beta$, and almost no effect on $E R \alpha$. Compound $\mathbf{6 b}$ showed antagonistic activity in ER $\beta$, already pointing at the potential of benzonaphthofuran 3 to be converted into an ER $\beta$ antagonist through the introduction of the BSC.

Interestingly, when a BSC was introduced, as in $\mathbf{9 c}$ and $\mathbf{9 f}$, full 
$\mathrm{ER} \beta$ antagonists were obtained, with an $\mathrm{IC}_{50}$ of $0.183 \pm 0,007$ and $0.148 \pm 0,0068 \mu \mathrm{M}$, respectively, while they were completely devoid of activity against the $\alpha$ receptor at the same concentration range. These results are in agreement with the predicted lack of 5 interaction of the BSC with ERa Asp351 carboxylate for most of the here reported compounds (see docking studies). Thus, although these ligands possessed low RBAs, and did not show any significant subtype preference in binding assays, they proved to share significant degrees of antagonism on ER $\beta$. Given the

10 limited number of examples of ER $\beta$-selective antagonists available ${ }^{4}$ these compounds could be used as potential molecular probes to differentiate the biological roles of both ER subtypes.

\section{In Vitro Antiproliferative Activity}

${ }_{15}$ Compounds $6 \mathbf{b}, 9 \mathbf{c}$ and $9 \mathbf{f}$, characterized as full antagonists at low micromolar concentration, were selected for the assessment of antiproliferative potencies on human MCF-7 breast cancer line (Table 3). All of them displayed activity at higher concentrations, with $\mathrm{IC}_{50}$ within the range of 2.25 to $3.34 \mu \mathrm{M}$. This result is in 20 accordance with their antagonistic character. The modest antiproliferative activity observed was expected, as MCF-7 is a human breast cancer cell line showing a low level of ER $\beta$ expression.

Table 3 Agonistic and Antagonistic Profile and Antiproliferative 25 Activities of Selected Compounds.

\begin{tabular}{cccccc} 
& \multicolumn{2}{c}{$\begin{array}{c}\text { agonistic activity } \\
\left(\mathrm{EC}_{50}\right)(\mu \mathrm{M})\end{array}$} & \multicolumn{2}{c}{$\begin{array}{c}\text { antagonistic activity } \\
\left(\mathrm{IC}_{50}\right)^{\mathrm{a}}(\mu \mathrm{M})\end{array}$} & \\
\cline { 2 - 4 } ligand & MCF-7 $\mathrm{IC}_{50}{ }^{\mathrm{b}}$ \\
& $\mathrm{ER} \alpha$ & $\mathrm{ER} \beta$ & $\mathrm{ER} \alpha$ & $\operatorname{ER} \beta$ & $(\mu \mathrm{M})$ \\
6b & weak & - & - & $0.592 \pm 0.04$ & $2.42 \pm 0.38$ \\
9c & - & - & - & $0.148 \pm 0.0068$ & $3.34 \pm 0.71$ \\
9f & - & - & - & $0.183 \pm 0.007$ & $2.25 \pm 0.43$
\end{tabular}

a Experimental values represent the average of 2 experiments performed in triplicate along with standard deviation (SD) between assay values.

b Experimental values represent the average of 3 experiments performed in quintuplicate along with standard deviation (SD) between assay values.

\section{${ }_{30}$ Conclusions}

We have used the benzo[b]naphtho[1,2- $d]$ furan and benzo $[b]$ naphtho $[1,2-d]$ thiophene systems, previously described by us as selective $\beta$-agonists, ${ }^{17}$ to generate a series of antagonists by the introduction of the BSCs present in tamoxifen, raloxifene 35 and other antagonist described in the literature. The antagonism is thus produced through the establishment of an interaction between this BSC and Asp303 carboxylate (ER $\beta$ numbering), blocking the ER helix-12 movement. Docking studies on our compounds have pointed towards a clearly preferred ER $\beta$ 40 binding, and have allowed proposing binding modes exhibiting the interaction of the BSC and Asp303 carboxylate from helix-12. Among these novel ligands, compounds $9 \mathbf{c}$ and $9 f$ presented a promising profile, with low micromolar activity as ER $\beta$ antagonists in a cell-based functional assay, and no activity 45 in $E R \alpha$ at the same concentration range.

There are few examples of ligands with this $\beta$-selective antagonistic profile. The ability of these compounds to annul the estrogen action through ER $\beta$, without having any effect on its activity through $\mathrm{ER} \alpha$, could be used to differentiate the biological 50 roles of both ER subtypes.

\section{Experimental}

General Methods. Melting points (uncorrected) were determined on a Stuart Scientific SMP3 apparatus. Infrared (IR) spectra were 55 recorded with a Perkin-Elmer 1330 infrared spectrophotometer. ${ }^{1} \mathrm{H}$ and ${ }^{13} \mathrm{C}$ NMR were recorded on a Bruker 300 -AC instrument. Chemical shifts $(\delta)$ are expressed in parts per million; coupling constants $(J)$ are in Hertz. Mass spectra were run on a Bruker Esquire 3000 spectrometer. Thin-layer chromatography (TLC) 60 was run on Merck silica gel 60 F-254 plates. Unless stated otherwise, starting materials used were high-grade commercial products. Compounds 9a-c, 9f and $\mathbf{9 h}-\mathbf{j}$ were tested as hydrochlorides and their purities were determined by HPLC on an Agilent 1100 HPLC system with UV detector, using a C18 ${ }_{65}$ reversed-phase Discovery column $(15 \times 4,6 \mathrm{~mm}$ ID, $5 \mathrm{um})$, eluting with an isocratic $\mathrm{pH} 7$ phosphate buffer-methanol $(80: 20 \mathrm{v} / \mathrm{v})$ mobile phase.

(3,9-Methoxybenzo[b]naphtho[1,2-d]furan-5-yl)(4-

fluorophenyl)methanone $\mathbf{5 b}$. To a solution of $\mathbf{4} \mathbf{b}^{17}(0.98 \mathrm{~g}, 3.23$ $70 \mathrm{mmol})$ in THF $\left(20 \mathrm{~cm}^{3}\right)$ was added a solution of 4fluorophenylmagnesium bromide $\left(65 \mathrm{~cm}^{3}, 1 \mathrm{M}\right.$ in THF, $\left.65 \mathrm{mmol}\right)$ at RT, and the mixture was refluxed for $24 \mathrm{~h}$. After cooling, $\mathrm{HCl}$ $3 \mathrm{~N}\left(20 \mathrm{~cm}^{3}\right)$ was added to the crude, and a red solid, which was characterized as the imine of $\mathbf{5 b}$, precipitated. The solid was 75 isolated by filtration and after adding $\mathrm{HCl} 3 \mathrm{~N}\left(125 \mathrm{~cm}^{3}\right)$, the suspension was refluxed for $48 \mathrm{~h}$. The new yellow precipitate formed was extracted with DCM $\left(3 \times 20 \mathrm{~cm}^{3}\right)$ and the organic extracts were washed with brine, dried $\left(\mathrm{MgSO}_{4}\right)$, and evaporated to give $\mathbf{5 b}(1.26 \mathrm{~g}, 98 \%)$ as a yellow solid, $\mathrm{mp} 170-171{ }^{\circ} \mathrm{C} ; v_{\max }$ $80(\mathrm{KBr}) / \mathrm{cm}^{-1} 1620 ; \delta_{\mathrm{H}}\left(300 \mathrm{MHz}, \mathrm{CDCl}_{3}\right) 3.68(3 \mathrm{H}, \mathrm{s}, \mathrm{OMe}), 3.93$ (3 H, s, OMe), 7.07 (1 H, dd, J 2.4, 8.8, ArH), 7.15-7.20 (3 H, m, ArH), 7.39 (1 H, dd, $J$ 2.4, 9.3, ArH), 7.76 (1 H, d, $J$ 2.4, ArH), $7.81(1 \mathrm{H}, \mathrm{s}, \mathrm{ArH}), 7.94(2 \mathrm{H}, \mathrm{d}, J$ 8.8, $\operatorname{ArH}), 8.09(1 \mathrm{H}, \mathrm{d}, J$ 8.8, $\mathrm{ArH})$ and $8.36(1 \mathrm{H}, \mathrm{d}, J 8.8, \mathrm{ArH}) ; \delta_{\mathrm{C}}\left(75.4 \mathrm{MHz} ; \mathrm{CDCl}_{3}\right) 55.1$, ${ }_{85} 55.6,96.3,105.7,112.1,115.4,115.6,115.7,117.1,119.6,121.2$, $122.6,123.9,125.0,129.7,132.1,132.9,133.0,135.0,135.02$, $150.6,157.3,158.2,159.8,163.9,167.3$ and 195.9; EIMS (m/z) $400[\mathrm{M}]^{+}$.

\section{(3,9-Dihydroxybenzo $[b]$ naphtho[1,2-d] furan-5-yl)(4-}

90 fluorophenyl)methanone $\mathbf{6 b}$. To a solution of $\mathbf{5 b}(0.8 \mathrm{~g}, 2$ $\mathrm{mmol})$ in dry DCM $\left(20 \mathrm{~cm}^{3}\right)$, was added $\mathrm{BBr}_{3}\left(40 \mathrm{~cm}^{3}, 1 \mathrm{M}\right.$ in DCM, $40 \mathrm{mmol})$ at $0{ }^{\circ} \mathrm{C}$. The mixture was stirred in a sealed tube at $70{ }^{\circ} \mathrm{C}$ for $48 \mathrm{~h}$. After cooling to room temperature, the crude reaction mixture was quenched carefully with ice, water and $1 \mathrm{~N}$ ${ }_{95} \mathrm{HCl}$. The aqueous layer was extracted with AcOEt $\left(3 \times 50 \mathrm{~cm}^{3}\right)$ and the combined organic extracts were washed with saturated aqueous $\mathrm{NaHCO}_{3}$ and brine, dried $\left(\mathrm{MgSO}_{4}\right)$ and concentrated to dryness to give $6 \mathbf{b}(0.71 \mathrm{~g}, 95 \%)$ as a solid, mp $224-225^{\circ} \mathrm{C}$; $v_{\max }$ $(\mathrm{KBr}) / \mathrm{cm}^{-1} 1595$ and $3300 ; \delta_{\mathrm{H}}(300 \mathrm{MHz}, \mathrm{MeOD}) 6.95(1 \mathrm{H}, \mathrm{dd}$, ${ }_{100} J$ 2.4, 8.6, ArH), 7.00-7.04 (2 H, m, ArH), 7.09-7.14 (2 H, m, ArH), 7.25 (1 H, dd, J 2.4, 9.2, ArH), 7.59 (1 H, s, ArH), 7.66$7.71(2 \mathrm{H}, \mathrm{m}, \mathrm{ArH}), 8.15(1 \mathrm{H}, \mathrm{d}, J 8.6, \mathrm{ArH})$ and $8.45(1 \mathrm{H}, \mathrm{d}, J$ 9.2, $\mathrm{ArH}) ; \delta_{\mathrm{C}}(75.4 \mathrm{MHz} ; \mathrm{MeOD}) 99.3,109.8,113.5,116.4$, $116.8,117.7,120.3,123.6,124.2$, 126.6, 130.5, 131.9, 132.1, $105135.5,136.0,136.02,152.5,155.8,158.8,159.3,164.4,167.8$ and 
179.1; EIMS (m/z) $395[\mathrm{M}+\mathrm{Na}]^{+}$; HPLC purity: 96.52. (3,9-Dibenzyloxybenzo $[b]$ naphtho[1,2-d]furan-5-yl)(4-

fluorophenyl)methanone $7 \mathbf{b}$. A solution of $\mathbf{6 b}(0.5 \mathrm{~g}, 1.34$ $\mathrm{mmol}), \mathrm{K}_{2} \mathrm{CO}_{3}(3.2 \mathrm{~g}, 23 \mathrm{mmol})$ and benzyl bromide $\left(0.96 \mathrm{~cm}^{3}\right.$, $58,1 \mathrm{mmol})$ in $\operatorname{EtOH}\left(3 \mathrm{~cm}^{3}\right)$ was refluxed for $24 \mathrm{~h}$. The reaction was then diluted with AcOEt, washed with water and brine, dried $\left(\mathrm{MgSO}_{4}\right)$ and evaporated to dryness. The residue was purified by flash column chromatography using hexane-AcOEt $(9: 1)$ as eluent to give $7 \mathbf{b}(0.72 \mathrm{~g}, 82 \%)$ as a yellow solid, $\mathrm{mp} 155-157^{\circ} \mathrm{C}$; $10 v_{\max }(\mathrm{KBr}) / \mathrm{cm}^{-1} 1590$ and $3020 ; \delta_{\mathrm{H}}\left(300 \mathrm{MHz}, \mathrm{CDCl}_{3}\right) 5.11(2 \mathrm{H}$, s, $\left.\mathrm{CH}_{2} \mathrm{O}\right), 5.12\left(2 \mathrm{H}, \mathrm{s}, \mathrm{CH}_{2} \mathrm{O}\right), 7.14-7.20(3 \mathrm{H}, \mathrm{m}, \mathrm{ArH}), 7.36-$ 7.50 (12 H, m, ArH), 7.82-7.86 (2 H, m, ArH), 7.93-7.95 (2 H, m, $\operatorname{ArH}), 8.27(1 \mathrm{H}, \mathrm{d}, J 7.8, \mathrm{ArH})$ and $8.56(1 \mathrm{H}, \mathrm{d}, J 8.8, \mathrm{ArH})$; $\delta_{\mathrm{C}}\left(75.4 \mathrm{MHz} ; \mathrm{CDCl}_{3}\right)$ 69.8, 70.3, 97.4, 106.9, 112.7, 115.4, $15115.5,115.7,117.3,119.9,121.1,122.7,124.0,125.0,127.6$, $127.9,128.1,128.5,129.6,132.2,132.9,133.0,134.8,134.9$, $136.3,136.5,150.76,156.5,158.1,158.8,163.9,167.3$ and 195.9; $\operatorname{EIMS~}(\mathrm{m} / \mathrm{z}) 553[\mathrm{M}+\mathrm{H}]^{+}$.

(3,9-Dibenzyloxybenzo $[b]$ naphtho[1,2- $d]$ tiophen-5-yl)(4-[2-

$20(\mathrm{~N}, \mathrm{~N}$-dimethyl)ethoxylphenyl)methanone $8 \mathrm{~b}$. To a solution of 2-(dimethylamino)ethanol $(0.31 \mathrm{~g}, 3.5 \mathrm{mmol})$ in DMF $\left(5 \mathrm{~cm}^{3}\right)$ was added $\mathrm{NaH}(0.08 \mathrm{~g}, 3.5 \mathrm{mmol})$ and the mixture was stirred at RT for $30 \mathrm{~min}$. Then $7 \mathbf{a}^{17}(0.1 \mathrm{~g}, 0.18 \mathrm{mmol})$ was added, and the stirring was continued for $6 \mathrm{~h}$. To the solution was added water, 25 and the aqueous layer was extracted with AcOEt, washed with brine, dried $\left(\mathrm{MgSO}_{4}\right)$ and evaporated. The residue was purified by flash column chromatography using AcOEt-MeOH $(9: 1)$ as eluent to give $\mathbf{8 b}(0.086 \mathrm{~g}, 77 \%)$ as a yellow oil; $v_{\max }(\mathrm{KBr}) / \mathrm{cm}^{-1}$ 1597 and 2931; $\delta_{\mathrm{H}}\left(300 \mathrm{MHz}, \mathrm{CDCl}_{3}\right) 2.37\left(6 \mathrm{H}, \mathrm{s}, 2 \mathrm{CH}_{3}\right), 2.75-$ $302.84\left(2 \mathrm{H}, \mathrm{m}, \mathrm{CH}_{2} \mathrm{~N}\right), 4.11-4.20\left(2 \mathrm{H}, \mathrm{m}, \mathrm{CH}_{2} \mathrm{O}\right), 5.08(2 \mathrm{H}, \mathrm{s}$, $\left.\mathrm{CH}_{2} \mathrm{O}\right), 5.18\left(2 \mathrm{H}, \mathrm{s}, \mathrm{CH}_{2} \mathrm{O}\right), 6.99(2 \mathrm{H}, \mathrm{d}, J$ 7.8, $\mathrm{ArH}), 7.24-7.49$ (13 H, m, ArH), 7.76 (1 H, s, ArH), 7.90-7.7.92 (3 H, m, ArH), $8.68(1 \mathrm{H}, \mathrm{d}, J 8.8 \mathrm{~Hz}, \mathrm{ArH})$ and $8.90(1 \mathrm{H}, \mathrm{d}, J 9.3 \mathrm{~Hz}, \mathrm{ArH})$; $\delta_{\mathrm{C}}\left(75.4 \mathrm{MHz} ; \mathrm{CDCl}_{3}\right) 45.8,58.0,66.1,69.8,70.2,106.9,107.4$, $35114.2,114.8,119.3,123.3,124.7,125.6,125.8,127.5,127.7$, $127.9,128.1,128.5,128.6,129.8,131.0,131.1,131.3,132.7$, $133.3,133.7,136.4,136.5,142.6,156.3,157.3,163.0$ and 196.4; EIMS $(\mathrm{m} / \mathrm{z}) 638[\mathrm{M}+\mathrm{H}]^{+}$.

\section{(3,9-Dibenzyloxybenzo $[b]$ naphtho[1,2- $d]$ thien-5-yl)(4-[1-}

40 methylpiperidine-4-iloxy]phenyl)methanone $8 \mathrm{c}$. The procedure described above for $\mathbf{8 b}$ was used for the synthesis of $\mathbf{8 c}$. From $\mathbf{7 a}$ (0.1 g, $0.18 \mathrm{mmol})$, 1-methylpiperidine-4-ol $(0.41 \mathrm{~g}, 3.5 \mathrm{mmol})$ and $\mathrm{NaH}(0.08 \mathrm{~g}, 3.5 \mathrm{mmol}), 8 \mathrm{c}(0.088 \mathrm{~g}, 76 \%)$ was obtained as a yellow oil. $v_{\max }(\mathrm{KBr}) / \mathrm{cm}^{-1} 1597$ and $2925 ; \delta_{\mathrm{H}}\left(300 \mathrm{MHz}, \mathrm{CDCl}_{3}\right)$ 45 1.84-1.99 (2 H, m, $\left.\mathrm{CH}_{2}\right), 2.00-2.15\left(2 \mathrm{H}, \mathrm{m}, \mathrm{CH}_{2}\right), 2.26-2.40(5$ $\left.\mathrm{H}, \mathrm{m}, \mathrm{CH}_{2} \mathrm{y} \mathrm{CH}_{3}\right), 2.64-2.79\left(2 \mathrm{H}, \mathrm{m}, \mathrm{CH}_{2}\right), 4.42-4.54(1 \mathrm{H}, \mathrm{m}$, $\mathrm{CH}), 5.08\left(2 \mathrm{H}, \mathrm{s}, \mathrm{CH}_{2} \mathrm{O}\right), 5.20\left(2 \mathrm{H}, \mathrm{s}, \mathrm{CH}_{2} \mathrm{O}\right), 6.95(2 \mathrm{H}, \mathrm{d}, J$ 7.8, ArH), 7.26-7.52 (13 H, m, ArH), 7.77 (1 H, s, ArH), 7.88$7.93(3 \mathrm{H}, \mathrm{m}, \mathrm{ArH}), 8.70(1 \mathrm{H}, \mathrm{d}, J 8.3, \mathrm{ArH})$ and $8.91(1 \mathrm{H}, \mathrm{d}, J$ $\left.{ }_{50} 8.8, \mathrm{ArH}\right) ; \delta_{\mathrm{C}}\left(75.4 \mathrm{MHz} ; \mathrm{CDCl}_{3}\right) 14.11,20.99,29.60,30.39$, $45.95,52.19,60.31,69.80,70.16,106.91,107.39,114.79$, $115.10,119.26,123.34,124.71,125.61,125.78,127.46,127.68$, $127.93,128.08,128.45,128.58,129.76,130.89,131.03,131.30$, $132.81,133.23,133.66,136.38,136.44,142.57,156.25,157.24$, 55 161.75 and 196.34; EIMS (m/z) $664[\mathrm{M}+\mathrm{H}]^{+}$.

(3,9-Dibenzyloxybenzo[b]naphtho[1,2-d] tien-5-yl)(4-[2(piperidine-1-yl)ethylamino]phenyl)methanone 8d. To a solution of 2-(piperidine-1-yl)ethylamine $(0.451 \mathrm{~g}, 3.52 \mathrm{mmol})$ in
DMF $\left(5 \mathrm{~cm}^{3}\right)$ was added $\mathrm{K}_{2} \mathrm{CO}_{3}(0.486 \mathrm{~g}, 3.5 \mathrm{mmol})$ and the 60 mixture was stirred at RT for 15 minutes. Then $7 \mathbf{a}(0.1 \mathrm{~g}, 0.18$ $\mathrm{mmol}$ ) was added and the stirring was continued for $6 \mathrm{~h}$ at 100 ${ }^{\circ} \mathrm{C}$. To the solution was added water, and the aqueous layer was extracted with AcOEt, washed with brine, dried $\left(\mathrm{MgSO}_{4}\right)$ and evaporated. The residue was purified by flash column ${ }_{65}$ chromatography using AcOEt as eluent to give $8 d$ ( $\left.0.101 \mathrm{~g}, 85 \%\right)$ as a yellow oil. $v_{\max }(\mathrm{KBr}) / \mathrm{cm}^{-1} 1591,2925$ and $3356 ; \delta_{\mathrm{H}}(300$ $\left.\mathrm{MHz}, \mathrm{CDCl}_{3}\right)$ 1.40-1.55 (2 H, m, $\left.\mathrm{CH}_{2}\right), 1.56-1.64(4 \mathrm{H}, \mathrm{m}$, $\left.2 \mathrm{CH}_{2}\right), 2.32-2.49\left(4 \mathrm{H}, \mathrm{m}, 2 \mathrm{CH}_{2} \mathrm{~N}\right), 2.56-2.58\left(2 \mathrm{H}, \mathrm{m}, \mathrm{CH}_{2} \mathrm{~N}\right)$, 3.19-3.20 (2 H, m, $\left.\mathrm{CH}_{2} \mathrm{~N}\right), 5.07\left(2 \mathrm{H}, \mathrm{s}, \mathrm{CH}_{2} \mathrm{O}\right), 5.15(2 \mathrm{H}, \mathrm{s}$, $\left.{ }_{70} \mathrm{CH}_{2} \mathrm{O}\right), 5.21(1 \mathrm{H}, \mathrm{s}, \mathrm{NH}), 6.57(2 \mathrm{H}, \mathrm{d}, J$ 8.8, ArH), 7.23-7.49 $(13 \mathrm{H}, \mathrm{m}, \mathrm{ArH}), 7.74(1 \mathrm{H}, \mathrm{d}, J 2.5$, ArH), $7.83(2 \mathrm{H}, \mathrm{d}, J 8.8$, $\mathrm{ArH}), 8.02(1 \mathrm{H}, \mathrm{s}, \mathrm{ArH}), 8.67(1 \mathrm{H}, \mathrm{d}, J$ 8.8, ArH), and 8.89 (1 $\mathrm{H}, \mathrm{d}, J$ 9.8, $\mathrm{ArH}) ; \delta_{\mathrm{C}}\left(75.4 \mathrm{MHz} ; \mathrm{CDCl}_{3}\right) 24.21,25.77,39.27$, $54.03,56.61,69.75,70.11,106.93,107.52,111.34,114.60$, 1 $119.10,122.26,124.58,125.56,126.49,127.43,127.67,127.83$, $127.99,128.38,128.52,129.89,130.57,131.06,133.07,133.46$, $134.91,136.42,136.49,142.28,152.73,156.01,157.03$ and 195.75; EIMS (m/z) $677[\mathrm{M}+\mathrm{H}]^{+}$.

(3,9-Dibenzyloxybenzo[b]naphtho[1,2-d]tien-5-yl)(4-[4-

${ }_{80}$ isopropylpiperazin-1-yl]phenyl)methanone $8 \mathrm{e}$. The procedure described above for $\mathbf{8 d}$ was used for the synthesis of $\mathbf{8 e}$. From 7a $(0.1 \mathrm{~g}, 0.18 \mathrm{mmol}), 4$-isopropylpiperazine $(0.451 \mathrm{~g}, 3.52 \mathrm{mmol})$ and $\mathrm{K}_{2} \mathrm{CO}_{3}(0.486 \mathrm{~g}, 3.5 \mathrm{mmol}), \mathbf{8 e}(0.1 \mathrm{~g}, 85 \%)$ was obtained as a yellow oil. $v_{\max }(\mathrm{KBr}) / \mathrm{cm}^{-1} 1591,2912$ and $3443 ; \delta_{\mathrm{H}}(300 \mathrm{MHz}$, $\left.{ }_{85} \mathrm{CDCl}_{3}\right) 1.09\left(6 \mathrm{H}, \mathrm{d}, J 6.4,2 \mathrm{CH}_{3}\right), 2.63-2.66\left(5 \mathrm{H}, \mathrm{m}, 2 \mathrm{CH}_{2} \mathrm{~N}\right.$ y $\mathrm{CH}), 3.37-3.39\left(4 \mathrm{H}, \mathrm{m}, 2 \mathrm{CH}_{2} \mathrm{~N}\right), 5.06\left(2 \mathrm{H}, \mathrm{s}, \mathrm{CH}_{2} \mathrm{O}\right), 5.14(2 \mathrm{H}$, s, $\left.\mathrm{CH}_{2} \mathrm{O}\right), 6.84(2 \mathrm{H}, \mathrm{d}, J$ 8.8, $\mathrm{ArH}), 7.24(1 \mathrm{H}, \mathrm{dd}, J$ 2.4, 9.3, ArH), 7.37-7.49 (12 H, m, ArH), 7.77 (1 H, d, J 2.9, ArH), 7.86 (2 H, d, J 8.8, ArH), $7.91(1 \mathrm{H}, \mathrm{s}, \mathrm{ArH}), 8.67(1 \mathrm{H}, \mathrm{d}, J 9.3, \mathrm{ArH})$ 90 and $8.89(1 \mathrm{H}, \mathrm{d}, J 9.8, \mathrm{ArH}) ; \delta_{\mathrm{C}}\left(75.4 \mathrm{MHz} ; \mathrm{CDCl}_{3}\right) 18.39,47.20$, 48.22 , 54.36, 69.77, 70.13, 106.91, 107.46, 112.89, 114.66, $119.17,122.68,124.62,125.59,125.65,127.44,127.62,127.69$, $127.86,128.02,128.39,128.54,129.84,130.81,131.07,132.62$, $133.37,134.43,136.40,136.48,142.39,154.23,156.11,157.09$ 95 and 195.86; EIMS (m/z) $677[\mathrm{M}+\mathrm{H}]^{+}$.

(3,9-Dihidroxybenzo $[b]$ naphtho[1,2-d]furan-5-yl)(4-[2-

(piperidin-1-yl)ethoxy]phenyl)methanone 8f. The procedure described above for $\mathbf{8 b}$ was used for the synthesis of $\mathbf{8 f}$. From 2(piperidin-1-yl)ethanol (0.47 g, $3.6 \mathrm{mmol}), \mathrm{NaH}(0.09 \mathrm{~g}, 3.6$ $100 \mathrm{mmol})$ and $7 \mathbf{b}(0.1 \mathrm{~g}, 0.18 \mathrm{mmol}), \quad 8 f \quad(0.114 \mathrm{~g}, 96 \%)$ was obtained as a yellow oil. $v_{\max }(\mathrm{KBr}) / \mathrm{cm}^{-1} 1590$ and $3020 ; \delta_{\mathrm{H}}(300$ $\left.\mathrm{MHz}, \mathrm{CDCl}_{3}\right)$ 1.40-1.50 (2 H, m, $\left.\mathrm{CH}_{2}\right), 1.58-1.61\left(4 \mathrm{H}, \mathrm{m}, \mathrm{CH}_{2}\right)$, 2.45-2.64 (4 H, m, $\left.\mathrm{CH}_{2}\right), 2.78-2.89\left(2 \mathrm{H}, \mathrm{m}, \mathrm{CH}_{2} \mathrm{~N}\right), 4.15-4.27$ (2 $\left.\mathrm{H}, \mathrm{m}, \mathrm{CH}_{2} \mathrm{O}\right), 5.08\left(2 \mathrm{H}, \mathrm{s}, \mathrm{CH}_{2} \mathrm{O}\right), 5.18\left(2 \mathrm{H}, \mathrm{s}, \mathrm{CH}_{2} \mathrm{O}\right), 6.97(2$ ${ }_{105} \mathrm{H}, \mathrm{d}, J$ 7.3, ArH), 7.17 (1 H, m, ArH), $7.25(1 \mathrm{H}, \mathrm{m}, \mathrm{ArH}), 7.35-$ $7.52(11 \mathrm{H}, \mathrm{m}, \mathrm{ArH}), 7.79-7.80(2 \mathrm{H}, \mathrm{m}, \mathrm{ArH}), 7.90(2 \mathrm{H}, \mathrm{d}, J$ 7.3, ArH), $8.24(1 \mathrm{H}, \mathrm{d}, J 7.83, \mathrm{ArH})$ and $8.53(1 \mathrm{H}, \mathrm{d}, J 8.28$, $\mathrm{ArH}) ; \delta_{\mathrm{C}}\left(75.4 \mathrm{MHz} ; \mathrm{CDCl}_{3}\right)$ 24.01, 25.78, 54.96, 57.58, 66.15, $69.82,70,35,97.49,107.06,112.61,114.18,114.70,117.55$, $10119.90,120.38,122.56,124.05,124.99,127.46,127.66,127.90$, $128.05,128.43,128.57,129.58,131.07,132.75,133.53,136.36$, $136.50,151.05,156.27,157.95,158.66,162.92$ and 196.17; $\operatorname{EIMS~}(\mathrm{m} / \mathrm{z}) 662[\mathrm{M}+\mathrm{H}]^{+}$.

(3,9-Dibenzyloxybenzo[b] naphtho[1,2-d]furan-5-yl)(4-[2-

15 ( $\mathbf{N}, \mathbf{N}$-dimethyl)ethoxy]phenyl)methanone $\mathbf{8 g}$. The same procedure described above for $\mathbf{8 b}$ was used for the synthesis of 
8g. From $7 \mathbf{b}(0.1 \mathrm{~g}, 0.18 \mathrm{mmol}), 2$-(dimethylamino)ethanol (0.32 g, $3.6 \mathrm{mmol})$ and $\mathrm{NaH}(0.09 \mathrm{~g}, 3.6 \mathrm{mmol}), \mathbf{8 g}(0.104 \mathrm{~g}, 93 \%)$ was obtained as a yellow oil. $v_{\max }(\mathrm{KBr}) / \mathrm{cm}^{-1} 1594$ and $2931 ; \delta_{\mathrm{H}}(300$ $\left.\mathrm{MHz}, \mathrm{CDCl}_{3}\right) 2.37\left(6 \mathrm{H}, \mathrm{s}, 2 \mathrm{CH}_{3}\right), 2.73-2.86\left(2 \mathrm{H}, \mathrm{m}, \mathrm{CH}_{2} \mathrm{~N}\right)$, 5 4.12-4.21 (2 H, m, CH$), 5.08\left(2 \mathrm{H}, \mathrm{s}, \mathrm{CH}_{2} \mathrm{O}\right), 5.16(2 \mathrm{H}, \mathrm{s}$, $\left.\mathrm{CH}_{2} \mathrm{O}\right), 6.99(2 \mathrm{H}, \mathrm{d}, J$ 7.8, $\mathrm{ArH}), 7.14-7.17(1 \mathrm{H}, \mathrm{m}, \mathrm{ArH}), 7.23$ (1 H, s, ArH), 7.36-7.51 (11 H, m, ArH), 7.80-7.82 (2 H, m, $\mathrm{ArH}), 7.91(2 \mathrm{H}, \mathrm{d}, J$ 7.3, ArH $), 8.23(1 \mathrm{H}, \mathrm{d}, J$ 7.80, ArH) and $8.51(1 \mathrm{H}, \mathrm{d}, J 8.31, \mathrm{ArH}) ; \delta_{\mathrm{C}}\left(75.4 \mathrm{MHz} ; \mathrm{CDCl}_{3}\right) 45.78,57.93$, ${ }_{10} 66.10,69.79,70.31,97.45,107.05,112.59,114.15,114.73$, $117.51,119.87,120.38,122.54,124.03,124.97,127.44,127.65$, $127.88,128.03,128.42,128.55,129.57,131.12,132.72,133.47$, $136.34,136.49,151.01,156.25,157.92,158.64,162.89$ and 196.13; EIMS (m/z) $621[\mathrm{M}+\mathrm{H}]^{+}$.

\section{5 (3,9-Dibenzyloxybenzo[b] naphtho[1,2-d] furan-5-yl)(4-[1-} methylpiperidine-4-iloxy]phenyl)methanone $8 \mathrm{~h}$. The procedure described above for $\mathbf{8 b}$ was used for the synthesis of $\mathbf{8 h}$. From $\mathbf{7 b}$ (0.1 g, $0.18 \mathrm{mmol})$, 1-methylpiperidine-4-ol (0.42 g, $3.6 \mathrm{mmol})$ and $\mathrm{NaH}(0.09 \mathrm{~g}, 3.6 \mathrm{mmol}), \mathbf{8 h}(0.1 \mathrm{~g}, 85 \%)$ was obtained as a 20 yellow oil. $v_{\max }(\mathrm{KBr}) / \mathrm{cm}^{-1} 1594$ and $2931 ; \delta_{\mathrm{H}}\left(300 \mathrm{MHz}, \mathrm{CDCl}_{3}\right)$ 1.82-2.00 (2 H, m, $\left.\mathrm{CH}_{2}\right), 2.01-2.16\left(2 \mathrm{H}, \mathrm{m}, \mathrm{CH}_{2}\right), 2.28-2.46(5$ $\mathrm{H}, \mathrm{m}, \mathrm{CH}_{3}$ у $\left.\mathrm{CH}_{2} \mathrm{~N}\right), 2.67-2.79\left(2 \mathrm{H}, \mathrm{m}, \mathrm{CH}_{2} \mathrm{~N}\right), 4.42-4.52(1 \mathrm{H}$, m, CH), $5.08\left(2 \mathrm{H}, \mathrm{s}, \mathrm{CH}_{2} \mathrm{O}\right), 5.17\left(2 \mathrm{H}, \mathrm{s}, \mathrm{CH}_{2} \mathrm{O}\right), 6.95(2 \mathrm{H}, \mathrm{d}, J$ 7.8, ArH), 7.15-7.16 (1 H, m, ArH), 7.24 (1 H, s, ArH), 7.35-7.51 $25(11 \mathrm{H}, \mathrm{m}, \mathrm{ArH}), 7.80-7.82(2 \mathrm{H}, \mathrm{m}, \mathrm{ArH}), 7.90(2 \mathrm{H}, \mathrm{d}, J 7.8$, $\mathrm{ArH}), 8.24(1 \mathrm{H}, \mathrm{d}, J$ 8.28, ArH) and $8.52(1 \mathrm{H}, \mathrm{d}, J 8.28, \mathrm{ArH})$; $\delta_{\mathrm{C}}\left(75.4 \mathrm{MHz} ; \mathrm{CDCl}_{3}\right)$ 30.43, 45.99, 52.27, 69.81, 70.34, 97.48, $107.07,112.61,114.72,115.08,117.54,119.87,120.39,122.57$, $124.06,124.99,127.46,127.67,127.91,128.06,128.44,128.57$, $30129.58,130.93,132.84,133.49,136.35,136.50,151.04,156.27$, 157.94, 158.66, 161.70 and 196.10; EIMS (m/z) $648[\mathrm{M}+\mathrm{H}]^{+}$.

(3,9-Dibenzyloxybenzo[b]naphtho[1,2-d]furan-5-yl)(4-[2(piperidine-1-yl)ethylamino]phenyl)methanone $8 \mathbf{i}$. The procedure described above for $\mathbf{8 d}$ was used for the synthesis of ${ }_{35} \mathbf{8 i}$. From $7 \mathbf{b}(0.1 \mathrm{~g}, 0.18 \mathrm{mmol})$, of 2-(piperidine-1-yl)ethylamine (0.463 g, $3.62 \mathrm{mmol})$ and $\mathrm{K}_{2} \mathrm{CO}_{3}(0.5 \mathrm{~g}, 3.62 \mathrm{mmol}), \mathbf{8 i}(0.101 \mathrm{~g}$, $85 \%)$ was obtained as a yellow oil. $v_{\max }(\mathrm{KBr}) / \mathrm{cm}^{-1} 1591,2925$ and 3356; $\delta_{\mathrm{H}}\left(300 \mathrm{MHz}, \mathrm{CDCl}_{3}\right)$ 1.45-1.48 $\left(2 \mathrm{H}, \mathrm{m}, \mathrm{CH}_{2}\right), 1.58-$ $1.62\left(4 \mathrm{H}, \mathrm{m}, \mathrm{CH}_{2}\right), 2.38-2.50\left(4 \mathrm{H}, \mathrm{m}, \mathrm{CH}_{2}\right), 2.58-2.62(2 \mathrm{H}, \mathrm{m}$, $\left.{ }_{40} \mathrm{CH}_{2} \mathrm{~N}\right), 3.20-3.26\left(2 \mathrm{H}, \mathrm{m}, \mathrm{CH}_{2} \mathrm{~N}\right), 5.08\left(2 \mathrm{H}, \mathrm{s}, \mathrm{CH}_{2} \mathrm{O}\right), 5.19(3$ $\mathrm{H}, \mathrm{m}, \mathrm{CH}_{2} \mathrm{O}$ y NH$), 6.59(2 \mathrm{H}, \mathrm{d}, J 8.8, \mathrm{ArH}), 7.17(1 \mathrm{H}, \mathrm{dd}, J$ 2.4, 8.8, ArH), 7.26-7.28 (1 H, m, ArH), 7.31-7.55 (11 H, m, ArH), 7.74 (1 H, d, J 2.4, ArH), 7.80-7.83 (3 H, m, ArH), 8.25 (1 $\mathrm{H}, \mathrm{d}, J 8.8, \mathrm{ArH})$ and $8.53(1 \mathrm{H}, \mathrm{d}, J 8.8, \mathrm{ArH}) ; \delta_{\mathrm{C}}(75.4 \mathrm{MHz}$; ${ }_{45} \mathrm{CDCl}_{3}$ ) 24.22, 25.77, 39.28, 54.06, 56.62, 69.81, 70.34, 97.52, $107.19,111.34,112.42,113.71,117.73,119.52,119.76,122.39$, $124.043,124.90,126.51,127.45,127.69,127.84,128.01,128.40$, 128.54, 129.54, 133.14, 134.94, 136.42, 136.57, 151.33, 152.71, 156.01, 157.73, 158.43 and 195.57; EIMS (m/z) $661[\mathrm{M}+\mathrm{H}]^{+}$.

(3,9-Dibenzyloxybenzo $[b]$ naphtho[1,2- $d]$ furan-5-yl)(4-[4isopropylpiperazin-1-yl]phenyl)methanone $8 \mathbf{j}$. The procedure described above for $\mathbf{8 d}$ was used for the synthesis of $\mathbf{8 j}$. From $\mathbf{7 b}$ $(0.1 \mathrm{~g}, 0.18 \mathrm{mmol}), 4$-isopropylpiperazine $(0.463 \mathrm{~g}, 3.62 \mathrm{mmol})$ ${ }_{55}$ and $\mathrm{K}_{2} \mathrm{CO}_{3}(0.5 \mathrm{~g}, 3.62 \mathrm{mmol}), \mathbf{8 j}(0.101 \mathrm{~g}, 85 \%)$ was obtained as a yellow oil. $v_{\max }(\mathrm{KBr}) / \mathrm{cm}^{-1} 1588$ and $2962 ; \delta_{\mathrm{H}}(300 \mathrm{MHz}$, $\left.\mathrm{CDCl}_{3}\right) 1.10\left(6 \mathrm{H}, \mathrm{d}, J 6.4,2 \mathrm{CH}_{3}\right), 2.66-2.78\left(5 \mathrm{H}, \mathrm{m}, 2 \mathrm{CH}_{2} \mathrm{y}\right.$ $\mathrm{CH}), 3.40-3.43\left(4 \mathrm{H}, \mathrm{m}, 2 \mathrm{CH}_{2}\right), 5.08\left(2 \mathrm{H}, \mathrm{s}, \mathrm{CH}_{2} \mathrm{O}\right), 5.19(2 \mathrm{H}, \mathrm{s}$,
$\left.\mathrm{CH}_{2} \mathrm{O}\right), 6.88$ (2 H, d, J 9.3, ArH), $7.17(1 \mathrm{H}, \mathrm{dd}, J 2.5,8.8, \mathrm{ArH})$, 607.27 (1 H, d, J 2.0, ArH), 7.37-7.50 (11 H, m, ArH), 7.77 (1 H, d, $J$ 2.4, ArH), 7.80 (1 H, s, ArH), 7.84 (2 H, d, $J$ 8.8, ArH), 8.26 (1 $\mathrm{H}, \mathrm{d}, J 8.8, \mathrm{ArH})$ and $8.53(1 \mathrm{H}, \mathrm{d}, J 9.3, \mathrm{ArH}) ; \delta_{\mathrm{C}}(75.4 \mathrm{MHz}$; $\left.\mathrm{CDCl}_{3}\right) 18.41,47.29,48.27,54.39,69.85,70.37,97.57,107.24$, $112.50,112.92,114.08,117.70,119.82,122.46,124.07,124.92$, ${ }_{65} 127.45,127.69,127.86,128.02,128.41,128.55,129.59,132.67$, $134.46,136.43,136.58,151.26,154.26,156.13,157.83,158.53$ and 195.66; EIMS (m/z) $661[\mathrm{M}+\mathrm{H}]^{+}$.

\section{(3,9-Dihidroxybenzo $[b]$ naphtho[1,2- $d]$ tien-5-yl)(4-[2-}

70 (piperidine-1-yl)ethoxylphenyl)methanone 9a. To a solution of $\mathbf{8 a}^{17}$ (0.096 g, $\left.0.142 \mathrm{mmol}\right)$ in EtOH/AcOEt/ $\mathrm{H}_{2} \mathrm{O}$ 7:3:1 $\left(10 \mathrm{~cm}^{3}\right)$ was added ammonium formiate $(0.29 \mathrm{~g}, 4.26 \mathrm{mmol})$ and black palladium $(0.015 \mathrm{~g}, 0.142 \mathrm{mmol})$ and the mixture was stirred at reflux for $3 \mathrm{~h}$. The black palladium was eliminated by filtration 75 and the solvent was evaporated. The residue was purified by flash column chromatography using DCM-MeOH 9:1 as eluent to give 9a $(0.064 \mathrm{~g}, 90 \%)$ as a yellow oil; $\delta_{\mathrm{H}}(300 \mathrm{MHz}, \mathrm{MeOD}) 1.43-$ $1.47\left(2 \mathrm{H}, \mathrm{m}, \mathrm{CH}_{2}\right), 1.64-1.68\left(4 \mathrm{H}, \mathrm{m}, 2 \mathrm{CH}_{2}\right), 3.00-3.06(4 \mathrm{H}, \mathrm{m}$, $\left.2 \mathrm{CH}_{2} \mathrm{~N}\right), 3.20-3.25\left(2 \mathrm{H}, \mathrm{m}, \mathrm{CH}_{2} \mathrm{~N}\right), 4.09-4.12\left(2 \mathrm{H}, \mathrm{m}, \mathrm{CH}_{2} \mathrm{O}\right)$, ${ }_{80} 6.77$ (2 H, d, $J$ 9.2, ArH), 7.02 (1 H, dd, $J$ 2.4, 8.6, ArH), 7.22$7.26(2 \mathrm{H}, \mathrm{m}, \mathrm{ArH}), 7.32(1 \mathrm{H}, \mathrm{d}, J 2.4, \operatorname{ArH}), 7.62(1 \mathrm{H}, \mathrm{s}, \mathrm{ArH})$, $7.65(2 \mathrm{H}, \mathrm{d}, J$ 8.6, ArH), $8.42(2 \mathrm{H}, \mathrm{m}, 2 \mathrm{OH}), 8.55(1 \mathrm{H}, \mathrm{d}, J 9.2$, ArH) and $8.79(1 \mathrm{H}, \mathrm{d}, J$ 9.2, $\mathrm{ArH})$; EIMS $(\mathrm{m} / \mathrm{z}) 498[\mathrm{M}+\mathrm{H}]^{+}$. To 9a was added a solution of $\mathrm{HCl}$ saturated ether and the 85 solution was stirred overnight to give the hydrochloride compound as a solid which was isolated by filtration, mp 217-218 ${ }^{\circ} \mathrm{C} ; v_{\max }(\mathrm{KBr}) / \mathrm{cm}^{-1} 1600,2680$ and $3200 ; \delta_{\mathrm{H}}(300 \mathrm{MHz}, \mathrm{DMSO})$ 1.67-1.79 (6 H, m, $\mathrm{CH}_{2}$-piperidine), 2.98-3.01 (2 H, m, $\mathrm{CH}_{2^{-}}$ piperidine), 3.45-3.58 (4 $\mathrm{H}, \mathrm{m}, \mathrm{CH}_{2}$-piperidine, $\left.\mathrm{CH}_{2} \mathrm{~N}\right), 4.45-5.52$ $90\left(2 \mathrm{H}, \mathrm{m}, \mathrm{CH}_{2} \mathrm{O}\right), 7.11-7.16(3 \mathrm{H}, \mathrm{m}, \mathrm{ArH}), 7.27(1 \mathrm{H}, \mathrm{d}, J$ 2.5, $\operatorname{ArH}), 7.33$ (1 H, dd, $J 2.5,9.2, \operatorname{ArH}), 7.48$ (1 H, dd, $J 1.8, \operatorname{ArH})$, 7.81-8.03 (2 H, m, ArH), 8.03 (1 H, s, ArH), 8.77 (1 H, d, J 9.2, $\mathrm{ArH}), 8.95$ (1 H, d, J 9.2, ArH), $9.94(1 \mathrm{H}, \mathrm{s}, \mathrm{OH}), 10.05(1 \mathrm{H}, \mathrm{s}$, $\mathrm{NH})$ and $10.16(1 \mathrm{H}, \mathrm{s}, \mathrm{OH}) ; \delta_{\mathrm{C}}(75.4 \mathrm{MHz}$; DMSO) 20.6, 21.9, ${ }_{95} 52.2,54.1,62.1,108.0,108.3,114.4,114.6,118.7,121.8,123.2$, $127.3,130.2,130.2,130.6,131.1,131.9,132.6,141.6,154.6$, 155.9, 161.3 and 195.3; EIMS (m/z) $498[\mathrm{M}+\mathrm{H}]^{+}$; HPLC > $94.38 \%$.

(3,9-Dihidroxybenzo $[b]$ naphtho $[1,2-d]$ tien-5-yl)(4-[2- $(N, N-$

100 dimethyl)ethoxy]phenyl)methanone $9 \mathrm{~b}$. The procedure described above was used for the synthesis of $\mathbf{9 b}$. From $\mathbf{8 b}(0.086$ $\mathrm{g}, 0.135 \mathrm{mmol})$, ammonium formiate $(0.255 \mathrm{~g}, 4.05 \mathrm{mmol})$ and black palladium $(0.014 \mathrm{~g}, 0.135 \mathrm{mmol})$ in $\mathrm{EtOH}\left(20 \mathrm{~cm}^{3}\right), 9 \mathbf{b}$ $(0.036 \mathrm{~g}, 59 \%)$ was obtained as a yellow oil. $\delta_{\mathrm{H}}(300 \mathrm{MHz}$, $105 \mathrm{MeOD}) 2.88\left(6 \mathrm{H}, \mathrm{s}, 2 \mathrm{CH}_{3}\right), 3.45-3.55\left(2 \mathrm{H}, \mathrm{m}, \mathrm{CH}_{2} \mathrm{~N}\right), 4.27-4.36$ $\left(2 \mathrm{H}, \mathrm{m}, \mathrm{CH}_{2} \mathrm{O}\right), 6.96-6-99$ ( $2 \mathrm{H}, \mathrm{d}, J$ 9.2, $\left.\mathrm{ArH}\right), 7.09$ (1 H, dd, $J$ 2.4, 8.6, ArH), 7.29-7.33 (2 H, m, ArH), $7.38(1 \mathrm{H}, \mathrm{d}, J$ 2.5, $\mathrm{ArH}), 7.75-7.79$ (3 H, m, ArH), $8.44(2 \mathrm{H}, \mathrm{m}, 2 \mathrm{OH}), 8.64(1 \mathrm{H}, \mathrm{d}$, $J$ 9.2, $\mathrm{ArH})$ and $8.87(1 \mathrm{H}, \mathrm{d}, J 9.8 \mathrm{~Hz}, \mathrm{ArH}) ; \delta_{\mathrm{C}}(75.4 \mathrm{MHz}$; $110 \mathrm{MeOD})$ 44.03, 57.48, 63.79, 109.28, 110.35, 115.52, 115,84, $119.83,123.98,125.90,126.26,127.18,129.91,132.57,132.83$, $133.00,133.43,133.84,134.45,144.14,156.39,157.70,163.39$ and 198.46. To $9 \mathbf{b}$ was added a solution of $\mathrm{HCl}$ saturated ether and the solution was stirred overnight to give the hydrochloride 115 compound as a solid which was isolated by filtration, mp 188-189 ${ }^{\circ} \mathrm{C} ; v_{\max }(\mathrm{KBr}) / \mathrm{cm}^{-1} 1600,2710$ and $3220 ; \delta_{\mathrm{H}}(300 \mathrm{MHz}, \mathrm{DMSO})$ 
$2.84\left(6 \mathrm{H}, \mathrm{s}, 2 \mathrm{CH}_{3}\right), 3.30-3.49\left(2 \mathrm{H}, \mathrm{m}, \mathrm{CH}_{2} \mathrm{~N}\right), 4.41-4.43(2 \mathrm{H}$, $\left.\mathrm{m}, \mathrm{CH}_{2} \mathrm{O}\right), 7.12-7.15$ (3 H, m, ArH), 7.24-7.25 (1 H, m, ArH), 7.30-7.35 (1 H, m, ArH), 7.46-7.49 (1 H, m, ArH), 7.81 (2 H, m, ArH), $8.02(1 \mathrm{H}, \mathrm{s}, \mathrm{ArH})$, 7.72-7.80 (1 H, m, ArH), 8.92-8.98 (1 $\left.{ }_{5} \mathrm{H}, \mathrm{m}, \mathrm{ArH}\right), 9.70(1 \mathrm{H}, \mathrm{s}, \mathrm{NH}), 9.92(1 \mathrm{H}, \mathrm{s}, \mathrm{OH})$ and $10.13(1 \mathrm{H}$, s, OH); EIMS (m/z) $458[\mathrm{M}+\mathrm{H}]^{+}$; HPLC purity: $91.27 \%$.

\section{(3,9-Dihidroxybenzo $[b]$ naphtho $[1,2-d]$ tien-5-yl)(4- $[1-$}

methylpiperidine-4-iloxy]phenyl)methanone 9c. The procedure described above was used for the synthesis of 9c. From 8c $(0.088$

$10 \mathrm{~g}, 0.133 \mathrm{mmol})$, ammonium formiate $(0.251 \mathrm{~g}, 3.99 \mathrm{mmol})$ and black palladium $(0.014 \mathrm{~g}, 0.133 \mathrm{mmol})$ in $\mathrm{EtOH} / \mathrm{AcOEt} / \mathrm{H}_{2} \mathrm{O} 7: 3$ : $1\left(20 \mathrm{~cm}^{3}\right), 9 c(0.048 \mathrm{~g}, 75 \%)$ was obtained as a yellow oil. $\delta_{\mathrm{H}}(300 \mathrm{MHz}, \mathrm{MeOD}) 1.90-2.08\left(2 \mathrm{H}, \mathrm{m}, \mathrm{CH}_{2}\right), 2.09-2.18(2 \mathrm{H}$, $\left.\mathrm{m}, \mathrm{CH}_{2}\right), 2.72\left(3 \mathrm{H}, \mathrm{s}, \mathrm{CH}_{3}\right), 3.02-3.15\left(2 \mathrm{H}, \mathrm{m}, \mathrm{CH}_{2} \mathrm{~N}\right), 3.16-3.27$

${ }_{15}\left(2 \mathrm{H}, \mathrm{m}, \mathrm{CH}_{2} \mathrm{~N}\right), 4.60-4.69(1 \mathrm{H}, \mathrm{m}, \mathrm{CH}), 6.95(2 \mathrm{H}, \mathrm{d}, J \mathrm{~T} .8$, ArH), 7.09-7.11 (1 H, m, ArH), 7.29-7.39 (3 H, m, ArH), 7.39 (1 H, s, ArH), 7.74-7.77 (3 H, m, ArH), 8.53 (2 H, m, 2OH), 8.65 (1 $\mathrm{H}, \mathrm{d}, J$ 9.2, ArH) and 8.88 (1 H, d, $J$ 8.6, ArH). To 9c was added a solution of $\mathrm{HCl}$ saturated ether and the solution was stirred 20 overnight to give the hydrochloride compound as a solid which was isolated by filtration, $\mathrm{mp} 187-188^{\circ} \mathrm{C} ; v_{\max }(\mathrm{KBr}) / \mathrm{cm}^{-1} 1600$, 2715 and 3230; $\delta_{\mathrm{H}}(300 \mathrm{MHz}, \mathrm{DMSO}) 1.87-2.28\left(4 \mathrm{H}, \mathrm{m}, 2 \mathrm{CH}_{2^{-}}\right.$ piperidinee), $2.76\left(3 \mathrm{H}, \mathrm{s}, \mathrm{CH}_{3}\right), 3.00-3.40\left(4 \mathrm{H}, \mathrm{m}, 2 \mathrm{xCH}_{2}-\right.$ piperidinee), 4.90 (1 H, m, CH-piperidinee), 7.11-7.18 (3 H, m, $\left.{ }_{25} \mathrm{ArH}\right), 7.28$ (1 H, s, ArH), 7.33 (1 H, dd, J 2.4, 9.2, ArH), 7.48 (1 $\mathrm{H}, \mathrm{d}, J$ 2.4, ArH), 7.78-7.82 (2 H, m, ArH), 8.04 (1 H, s, ArH), $8.76(1 \mathrm{H}, \mathrm{d}, J$ 9.2, ArH), $8.95(1 \mathrm{H}, \mathrm{d}, J$ 9.2, ArH $), 9.94(1 \mathrm{H}, \mathrm{s}$, $\mathrm{OH}), 10.06(1 \mathrm{H}, \mathrm{s}, \mathrm{OH})$ and $10.42(1 \mathrm{H}, \mathrm{s}, \mathrm{NH}) ; \delta_{\mathrm{C}}(75.4 \mathrm{MHz}$; MeOD) 41.47, 41.83, 47.99, 51.14, 65.99, 69.96, 107.98, 108.00, $30108.31,113.70,114.56,114.56,114.93,115.33,118.66,121.67$, $123.19,127.28,130.16,130.25,131.07,131.97,132.65,132.67$, 141.61, 154.57, 155.89, 160.45, 160.68 and 195.15; HPLC purity: $94.38 \%$.

\section{(3,9-Dihidroxybenzo $[b]$ naphtho[1,2- $d]$ tien-5-yl)(4-[2-}

35 (piperidine-1-yl)ethylamino]phenyl)methanone 9d. The procedure described above was used for the synthesis of 9d. From $8 d(0.093 \mathrm{~g}, 0.137 \mathrm{mmol})$, ammonium formiate $(0.258 \mathrm{~g}$, $4.12 \mathrm{mmol})$ and black palladium $(0.015 \mathrm{~g}, 0.137 \mathrm{mmol})$ in $\mathrm{MeOH}$ $\left(20 \mathrm{~cm}^{3}\right), 9 \mathrm{~d}(0.060 \mathrm{~g}, 90 \%)$ was obtained as a yellow oil. $\delta_{\mathrm{H}}(300$ $40 \mathrm{MHz}, \mathrm{MeOD}) .48-1.50\left(2 \mathrm{H}, \mathrm{m}, \mathrm{CH}_{2}\right), 1.65-1.69\left(4 \mathrm{H}, \mathrm{m}, 2 \mathrm{CH}_{2}\right)$, 2.83-2.90 $\left(6 \mathrm{H}, \mathrm{m}, 3 \mathrm{CH}_{2} \mathrm{~N}\right), 3.34-3.41\left(2 \mathrm{H}, \mathrm{m}, \mathrm{CH}_{2} \mathrm{~N}\right), 6.56(2 \mathrm{H}$, $\mathrm{d}, J$ 8.6, ArH), $7.10(1 \mathrm{H}, \mathrm{dd}, J 2.4,9.2, \mathrm{ArH}), 7.28-7.34(3 \mathrm{H}, \mathrm{m}$, ArH), 7.64 (2 H, d, J 9.2, ArH), $7.69(1 \mathrm{H}, \mathrm{s}, \mathrm{ArH}), 8.65(1 \mathrm{H}, \mathrm{d}$, $J$ 9.2, $\mathrm{ArH})$ and $8.88(1 \mathrm{H}, \mathrm{d}, J 9.8, \mathrm{ArH}) ; \delta_{\mathrm{C}}(75.4 \mathrm{MHz}$; MeOD) ${ }_{45} 22.81,24.26,38.56,54.55,56.51,109.36,110.48,112.63$, $115.80,119.80,122.83,125.87,126.17,126.18,126.99,127.78$, $130.03,132.13,132.57,133.64,134.34,135.63,143.85,154.18$, $156.14,157.50$ and 198.28 .

\section{(3,9-Dihidroxybenzo[b] naphtho[1,2- $d]$ tien-5-yl)(4-[4-}

${ }_{50}$ isopropylpiperazin-1-yl]phenyl)methanone $9 \mathrm{e}$. The procedure described above was used for the synthesis of $9 e$. From 8 e $(0.095$ $\mathrm{g}, 0.14 \mathrm{mmol})$, ammonium formiate $(0.265 \mathrm{~g}, 4.21 \mathrm{mmol})$ and black palladium $(0.015 \mathrm{~g}, 0.140 \mathrm{mmol}), 9 \mathrm{e}(0.069 \mathrm{~g}, 99 \%)$ was obtained as a yellow oil. $\delta_{\mathrm{H}}(300 \mathrm{MHz}, \mathrm{MeOD}) 1.02(6 \mathrm{H}, \mathrm{d}, J$ ${ }_{55}$ 6.7, $\left.2 \mathrm{CH}_{3}\right), 2.52-2.53\left(5 \mathrm{H}, \mathrm{m}, 2 \mathrm{CH}_{2}, \mathrm{CH}\right), 3.23-3.25(4 \mathrm{H}, \mathrm{m}$, $\left.2 \mathrm{CH}_{2} \mathrm{~N}\right), 6.76(2 \mathrm{H}, \mathrm{d}, J$ 9.2, $\mathrm{ArH}), 7.11(1 \mathrm{H}, \mathrm{dd}, J$ 2.4, 8.6, ArH), 7.28-7.34 (3 H, m, ArH), 7.67 (2 H, d, J 8.6, ArH), 7.74 (1 $\mathrm{H}, \mathrm{s}, \mathrm{ArH}), 8.68(1 \mathrm{H}, \mathrm{d}, J 8.6, \mathrm{ArH})$ and $8.90(1 \mathrm{H}, \mathrm{d}, J$ 9.2,
$\operatorname{ArH}) ; \delta_{\mathrm{C}}(75.4 \mathrm{MHz}$; MeOD) 18.09, 47.08, 49.24, 56.99, 109.35, ${ }_{60} 110.47,114.45,115.81,119.82,123.28,125.92,126.15,126.20$, $127.08,129.04,130.06,132.39,132.62,133.63,133.79,135.31$, $144.00,155.48,156.22,157.58$ and 198.35. To 9e was added a solution of $\mathrm{HCl}$ saturated ether and the solution was stirred overnight to give the hydrochloride compound as a solid which ${ }_{65}$ was isolated by filtration; $v_{\max }(\mathrm{KBr}) / \mathrm{cm}^{-1} 1595,2920$ and 3185 ; $\delta_{\mathrm{H}}(300 \mathrm{MHz}, \mathrm{DMSO}) 1.29\left(6 \mathrm{H}, \mathrm{d}, J 6.6,2 \mathrm{xCH}_{3}\right), 3.10-3.35(4$ $\left.\mathrm{H}, \mathrm{m}, 2 \mathrm{CH}_{2} \mathrm{~N}\right), 3.49-3.53\left(3 \mathrm{H}, \mathrm{m}, \mathrm{CH}_{2} \mathrm{~N}, \mathrm{CH}\right), 4.10-4.14(2 \mathrm{H}$, $\left.\mathrm{m}, \mathrm{CH}_{2} \mathrm{~N}\right), 7.08-7.14(3 \mathrm{H}, \mathrm{m}, \mathrm{ArH}), 7.24(1 \mathrm{H}, \mathrm{d}, J 2.5, \mathrm{ArH})$, 7.32 (1 H, dd, $J 2.6,9.1, \mathrm{ArH}), 7.47(1 \mathrm{H}, \mathrm{d}, J 2.5, \mathrm{ArH}), 7.71(2$ $70 \mathrm{H}, \mathrm{d}, J$ 8.9, ArH), 7.98 (1 H, s, ArH), 8.75 (1 H, d, J 9.2, ArH), 8.93 (1 H, d, J 9.2, ArH), 9.84 (1 H, s, OH), 10.06 (1 H, s, OH) and $10.11(2 \mathrm{H}, \mathrm{m}, 2 \mathrm{NH})$. HPLC purity: $92.49 \%$.

(3,9-Dihidroxybenzo[b]naphtho[1,2- $d]$ furan-5-yl)(4-[2-

(piperidine-1-yl)ethoxy]phenyl)methanone 9f. The procedure 75 described above was used for the synthesis of $9 f$. From $8 \mathbf{f}(0.113$ $\mathrm{g}, 0.170 \mathrm{mmol})$, ammonium formiate $(0.321 \mathrm{~g}, 5.1 \mathrm{mmol})$ and black palladium $(0.018 \mathrm{~g}, 0.170 \mathrm{mmol})$, 9f $(0.100 \mathrm{~g}, 85 \%)$ was obtained as a yellow oil. $\delta_{\mathrm{H}}(300 \mathrm{MHz}, \mathrm{MeOD}) 1.15-1.26(2 \mathrm{H}, \mathrm{m}$, $\mathrm{CH}_{2}$ ), 1.30-1.44 (4 H, m, $\left.\mathrm{CH}_{2}\right), 2.45-2.61\left(4 \mathrm{H}, \mathrm{m}, \mathrm{CH}_{2}\right), 2.70-$ $802.80\left(2 \mathrm{H}, \mathrm{m}, \mathrm{CH}_{2} \mathrm{~N}\right), 3.75-3.89\left(2 \mathrm{H}, \mathrm{m}, \mathrm{CH}_{2} \mathrm{O}\right), 6.55(2 \mathrm{H}, \mathrm{d}, J$ 7.9, ArH), 6.64-6.71 (2 H, m, ArH), 6.98-7.01 (1 H, m, ArH), 7.14-7.16 (1 H, m, ArH), 7.26-7.28 (1 H, m, ArH), 7.41 (2 H, d, $J$ 7.3, ArH), 7.85 (1 H, d, J 7.95, ArH), 8.15 (1 H, d, J 9.15, ArH) and $8.26(2 \mathrm{H}, \mathrm{m}, 2 \mathrm{OH}) ; \delta_{\mathrm{C}}(75.4 \mathrm{MHz}$; MeOD) 23.63, 25.07, ${ }_{85} 55.17,57.61,64.78,99.33,110.10,113.71,115.32,117.47$, $120.35,121.88,123.89,124.29,126.46,131.16,132.59,133.81$, $134.02,151.59,156.24,159.17,159.65,163.71$ and 198.05. To 9f was added a solution of $\mathrm{HCl}$ saturated ether and the solution was stirred overnight to give the hydrochloride compound as a solid 90 which was isolated by filtration, $\mathrm{mp} 267-268^{\circ} \mathrm{C} ; v_{\max }(\mathrm{KBr}) / \mathrm{cm}^{-1}$ 1620, 2720 and 3180; $\delta_{\mathrm{H}}(300 \mathrm{MHz}, \mathrm{DMSO}) 1.67-1.80(6 \mathrm{H}, \mathrm{m}$, $\mathrm{CH}_{2}$-piperidine), 2.92-3.10 (2 $\mathrm{H}, \mathrm{m}, \mathrm{CH}_{2}$-piperidine), 3.45-3.59 (4 H, m, $\mathrm{CH}_{2}$-piperidine, $\left.\mathrm{CH}_{2} \mathrm{~N}\right), 4.50-4.58\left(2 \mathrm{H}, \mathrm{m}, \mathrm{CH}_{2} \mathrm{O}\right), 7.02$ (1 H, dd, $J$ 1.9, 8.6 , ArH), 7.12-7.15 (3 H, m, ArH), 7.33-7.37 (2 $\left.{ }_{95} \mathrm{H}, \mathrm{m}, \mathrm{ArH}\right), 7.81-7-84$ (3 H, m, ArH), 8.39 (1 H, d, J 8.8, ArH), $8.63(1 \mathrm{H}, \mathrm{d}, J 8.8, \mathrm{ArH}), 9.86(1 \mathrm{H}, \mathrm{s}, \mathrm{NH}), 10.19(1 \mathrm{H}, \mathrm{s}, \mathrm{OH})$ and $10.70(1 \mathrm{H}, \mathrm{s}, \mathrm{OH}) ; \delta_{\mathrm{C}}(75.4 \mathrm{MHz}$; MeOD) 21.50, 22.30, $52.57,54.50,62.69,98.26,108.47,112.86,113.32,114.72$, $115.34,119.61,119.72,122.03,122.92,125.45,129.26,131.02$, $100132.35,132.81,149.74,154.94,157.57,157.89,161.70$ and 195.29; EIMS (m/z) $482[\mathrm{M}+\mathrm{H}]^{+}$. HPLC purity: $97.59 \%$. (3,9-Dihidroxybenzo $[b]$ naphtho[1,2- $d]$ furan-5-yl)(4-[2-(N,Ndimethyl)ethoxy]phenyl)methanone 9g. The procedure described above was used for the synthesis of 9 g. From 8 g $(0.101$ $105 \mathrm{~g}, 0.161 \mathrm{mmol})$, ammonium formiate $(0.304 \mathrm{~g}, 4.83 \mathrm{mmol})$ and black palladium, $9 \mathrm{~g}(0.067 \mathrm{~g}, 95 \%)$ was obtained as a yellow oil. $\delta_{\mathrm{H}}(300 \mathrm{MHz}, \mathrm{MeOD}) 2.88\left(6 \mathrm{H}, \mathrm{s}, 2 \mathrm{CH}_{3}\right), 3.42-3.55(2 \mathrm{H}, \mathrm{m}$, $\left.\mathrm{CH}_{2} \mathrm{~N}\right)$, 4.33-4.44 (2 H, m, $\left.\mathrm{CH}_{2} \mathrm{O}\right), 6.97-7.03$ (4 H, m, ArH), 7.30-7.33 (1 H, m, ArH), 7.43-7-45 (1 H, m, ArH), $7.66(1 \mathrm{H}, \mathrm{s}$, $10 \mathrm{ArH}), 7.81-7.84(2 \mathrm{H}, \mathrm{m}, \mathrm{ArH}), 8.23$ (1 H, d, J 9.15, ArH), 8.51 $(2 \mathrm{H}, \mathrm{m}, 2 \mathrm{OH})$ and $8.53(1 \mathrm{H}, \mathrm{d}, J 9.15, \mathrm{ArH})$. To $9 \mathrm{~g}$ was added a solution of $\mathrm{HCl}$ saturated ether and the solution was stirred overnight to give the hydrochloride compound as a solid which was isolated by filtration, $\mathrm{mp} 136-138^{\circ} \mathrm{C} ; v_{\max }(\mathrm{KBr}) / \mathrm{cm}^{-1} 1623$, 152700 and 3370; $\delta_{\mathrm{H}}(300 \mathrm{MHz}, \mathrm{DMSO}) 2.84\left(6 \mathrm{H}, \mathrm{s}, 2 \mathrm{CH}_{3}\right), 3.49-$ $3.56\left(2 \mathrm{H}, \mathrm{m}, \mathrm{CH}_{2}\right), 4.41-4.52\left(2 \mathrm{H}, \mathrm{m}, \mathrm{CH}_{2}\right), 7.00-7.02(1 \mathrm{H}, \mathrm{m}$, 
ArH), 7.10-7.20 (3 H, m, ArH), 7.32-7-35 (2 H, m, ArH), 7.81$7.84(3 \mathrm{H}, \mathrm{m}, \mathrm{ArH}), 8.39(1 \mathrm{H}, \mathrm{d}, J 8.6, \operatorname{ArH}), 8.63(1 \mathrm{H}, \mathrm{d}, J$ 8.6, ArH $), 9.89(1 \mathrm{H}, \mathrm{s}, \mathrm{OH}), 10.22(1 \mathrm{H}, \mathrm{s}, \mathrm{OH})$ and $10.34(1 \mathrm{H}, \mathrm{s}$, $\mathrm{NH}) ; \delta_{\mathrm{C}}(75.4 \mathrm{MHz}$; MeOD) 42.75, 55.09, 62.71, 98.32, 108.52, 5 112.95, 113.41, 114.83, 115.40, 119.70, 119.78, 122.09, 123.03, $125.56,129.32,131.10,132.42,132.87,149.81,155.00,157.63$, 157.96, 161.77 and 195.41; EIMS (m/z) $515[\mathrm{M}+\mathrm{H}]^{+}$

(3,9-Dihidroxybenzo $[b]$ naphtho[1,2-d] furan-5-yl)(4-[1methylpiperidine-4-iloxy]phenyl)methanone $9 \mathrm{~h}$. The procedure 10 described above was used for the synthesis of $\mathbf{9 h}$. From $\mathbf{8 h}(0.105$ g, $0.162 \mathrm{mmol})$, ammonium formiate $(0.306 \mathrm{~g}, 4.86 \mathrm{mmol})$ and black palladium $(0.017 \mathrm{~g}, 0.162 \mathrm{mmol}), 9 \mathrm{~h}(0.053 \mathrm{~g}, 71 \%)$ was obtained as a yellow oil. $\delta_{\mathrm{H}}(300 \mathrm{MHz}, \mathrm{MeOD}) 1.85-1.90(2 \mathrm{H}, \mathrm{m}$, $\left.\mathrm{CH}_{2}\right), 1.89-2.10\left(2 \mathrm{H}, \mathrm{m}, \mathrm{CH}_{2}\right), 2.29\left(3 \mathrm{H}, \mathrm{s}, \mathrm{CH}_{3}\right), 2.32-2.49(2$

$\left.{ }_{15} \mathrm{H}, \mathrm{m}, \mathrm{CH}_{2} \mathrm{~N}\right), 2.64-2.76\left(2 \mathrm{H}, \mathrm{m}, \mathrm{CH}_{2} \mathrm{~N}\right), 4.50-4.62(1 \mathrm{H}, \mathrm{m}, \mathrm{CH})$, 6.99-7.06 (4 H, m, ArH), 7.31-7.34 (1 H, m, ArH), 7.40-7.42 (1 $\mathrm{H}, \mathrm{m}, \mathrm{ArH}), 7.70$ (1 H, s, ArH), $7.82(2 \mathrm{H}, \mathrm{d}, J$ 8.0, ArH), 8.65 (1 $\mathrm{H}, \mathrm{d}, J 7.9, \mathrm{ArH})$ and $8.88(1 \mathrm{H}, \mathrm{d}, J 8.5, \mathrm{ArH})$. To $9 \mathbf{h}$ was added a solution of $\mathrm{HCl}$ saturated ether and the solution was stirred 20 overnight to give the hydrochloride compound as a solid which was isolated by filtration, $\mathrm{mp} 269-270{ }^{\circ} \mathrm{C} ; v_{\max }(\mathrm{KBr}) / \mathrm{cm}^{-1} 1625$, 2740 and $3160 ; \delta_{\mathrm{H}}(300 \mathrm{MHz}, \mathrm{DMSO}) 1.95-2.05\left(2 \mathrm{H}, \mathrm{m}, \mathrm{CH}_{2}\right)$, 2.10-2.25 (2 H, m, $\left.\mathrm{CH}_{2}\right), 2.73\left(3 \mathrm{H}, \mathrm{s}, \mathrm{CH}_{3}\right), 3.10-3.50(4 \mathrm{H}, \mathrm{m}$, $\left.2 \mathrm{CH}_{2}\right), 4.78-4.82(1 \mathrm{H}, \mathrm{m}, \mathrm{CH}), 6.99-7.06(1 \mathrm{H}, \mathrm{m}, \mathrm{ArH}), 7.11-$ 257.20 (3 H, m, ArH), 7.30-7.40 (2 H, m, ArH), 7.75-7.90 (3 H, m, ArH), 8.38 (1 H, d, J 7.9, ArH), 8.62 (1 H, d, J 8.5, ArH), 9.91 (1 $\mathrm{H}, \mathrm{s}, \mathrm{OH})$ and 10.23-10.25 $(2 \mathrm{H}, \mathrm{m}, \mathrm{OH}, \mathrm{NH}) ; \delta_{\mathrm{C}}(75.4 \mathrm{MHz}$; DMSO) 30.08, 45.42, 52.01, 98.33, 108.48, 112.87, 113.26, $115.46,119.59,119.66,122.08,123.03,125.56,129.30,130.17$, $30130.20,132.53,133.08,149.86,154.94,157.60,157.85,161.64$ and 195.26; EIMS (m/z) $468[\mathrm{M}+\mathrm{H}]^{+}$; HPLC purity: 98.60\%. (3,9-Dihidroxybenzo[b] naphtho[1,2- $d]$ furan-5-yl)(4-[2(piperidine-1-yl)ethylamino]phenyl)methanone $9 \mathrm{i}$. The procedure described above was used for the synthesis of $9 \mathbf{i}$. From ${ }_{35} \mathbf{8 i}(0.086 \mathrm{~g}, 0.130 \mathrm{mmol})$, ammonium formiate $(0.049 \mathrm{~g}, 0.78$ $\mathrm{mmol})$ and black palladium $(0.014 \mathrm{~g}, 0.130 \mathrm{mmol}), 9 \mathrm{i}(0.054 \mathrm{~g}$, $87 \%)$ was obtained as a yellow oil. $\delta_{\mathrm{H}}(300 \mathrm{MHz}, \mathrm{MeOD}) 1.39$ $1.41\left(2 \mathrm{H}, \mathrm{m}, \mathrm{CH}_{2}\right), 1.54-1.57\left(4 \mathrm{H}, \mathrm{m}, 2 \mathrm{CH}_{2}\right), 2.56-2.64(6 \mathrm{H}, \mathrm{m}$, $\left.3 \mathrm{CH}_{2} \mathrm{~N}\right), 3.22-3.27\left(2 \mathrm{H}, \mathrm{m}, \mathrm{CH}_{2} \mathrm{~N}\right), 6.49(2 \mathrm{H}, \mathrm{d}, J 8.6, \mathrm{ArH})$, $406.92(1 \mathrm{H}, \mathrm{dd}, J 1.8,8.6, \mathrm{ArH}), 7.00(1 \mathrm{H}, \mathrm{d}, J 2.4, \mathrm{ArH}), 7.25$ (1 $\mathrm{H}$, dd, $J$ 2.4, 9.2, ArH), $7.31(1 \mathrm{H}, \mathrm{d}, J 2.4$, ArH), $7.55(1 \mathrm{H}, \mathrm{s}$, ArH), 7.60 ( $2 \mathrm{H}, \mathrm{d}, J$ 8.5, ArH), $8.14(1 \mathrm{H}, \mathrm{d}, J 8.6, \mathrm{ArH})$ and $8.44\left(1 \mathrm{H}, \mathrm{d}, J\right.$ 9.2, ArH); $\delta_{\mathrm{C}}(75.4 \mathrm{MHz} ; \mathrm{MeOD}) 24.23,25.68$, $39.88,55.14,57.72,99.33,110.14,112.34,113.57,114.10$, 45 $117.73,120.28,121.01,123.71,124.33,126.38,127.19,131.11$, $134.42,135.64,152.00,154.76,155.91,158.91,159.50$ and 198.04. To $9 \mathbf{i}$ was added a solution of $\mathrm{HCl}$ saturated ether and the solution was stirred overnight to give the hydrochloride compound as a solid which was isolated by filtration, $\mathrm{mp}$ 235-236 ${ }_{50}^{\circ} \mathrm{C} ; \delta_{\mathrm{H}}(300 \mathrm{MHz}, \mathrm{DMSO}) 1.67-1.76\left(6 \mathrm{H}, \mathrm{m}, 3 \mathrm{CH}_{2}\right), 2.70-3.00(2$ $\left.\mathrm{H}, \mathrm{m}, \mathrm{CH}_{2}\right), 3.12-3.25\left(2 \mathrm{H}, \mathrm{m}, \mathrm{CH}_{2}\right), 3.55-3.60\left(4 \mathrm{H}, \mathrm{m}, 2 \mathrm{CH}_{2}\right)$, $6.70(2 \mathrm{H}, \mathrm{d}, J 8.5, \mathrm{ArH}), 7.00(1 \mathrm{H}, \mathrm{dd}, J 8.5, \mathrm{ArH}), 7.14(1 \mathrm{H}$, $\mathrm{m}, \mathrm{ArH}), 7.24(1 \mathrm{H}, \mathrm{m}, \mathrm{ArH}), 7.31(1 \mathrm{H}, \mathrm{dd}, J 8.5, \mathrm{ArH}), 7.62(2$ $\mathrm{H}, \mathrm{d}, J$ 8.5, ArH), 7.24 (1 H, s, ArH), $8.36(1 \mathrm{H}, \mathrm{d}, J$ 8.5, ArH), ${ }_{55} 8.59(1 \mathrm{H}, \mathrm{d}, J 9.2, \mathrm{ArH}), 9.81(1 \mathrm{H}, \mathrm{s}, \mathrm{OH})$ and 10.10-10.12 $(3 \mathrm{H}$, $\mathrm{m}, \mathrm{OH}, 2 \mathrm{xNH}) ; \delta_{\mathrm{C}}(75.4 \mathrm{MHz}$; DMSO) 21.35, 22.55, 36.92, $52.42,54.26,98.43,108.74,111.54,112.36,112.90,115.69$, $118.96,119.68,122.17,122.98,125.56,125.84,129.39,132.67$,
134.47, 150.14, 152.73, 154.75, 157.52, 157.74 and 194.52; ${ }_{60} \operatorname{EIMS}(\mathrm{m} / \mathrm{z}) 481[\mathrm{M}+\mathrm{H}]^{+}$; HPLC purity: $93.23 \%$.

\section{(3,9-Dihidroxybenzo $[b]$ naphtho[1,2-d] furan-5-yl)(4-[4-}

isopropylpiperazin-1-yl]phenyl)methanone $\mathbf{9 j}$. The procedure described above was used for the synthesis of $\mathbf{9 j}$. From $\mathbf{8 j}(0.101$ $\mathrm{g}, 0.153 \mathrm{mmol})$, ammonium formiate $(0.057 \mathrm{~g}, 0.918 \mathrm{mmol})$ and ${ }_{65}$ black palladium $(0.016 \mathrm{~g}, 0.153 \mathrm{mmol})$ in $\mathrm{MeOH} / \mathrm{AcOEt} 1: 1$ (10 $\left.\mathrm{cm}^{3}\right), 9 \mathbf{j}(0.058 \mathrm{~g}, 79 \%)$ was obtained as a yellow oil. $\delta_{\mathrm{H}}(300$ $\mathrm{MHz}, \mathrm{MeOD}) 0.96\left(6 \mathrm{H}, \mathrm{d}, J 6.7,2 \mathrm{CH}_{3}\right), 2.51-2.61(5 \mathrm{H}, \mathrm{m}$, $\left.2 \mathrm{CH}_{2} \mathrm{~N}, \mathrm{CH}\right), 3.15-3.29\left(4 \mathrm{H}, \mathrm{m}, 2 \mathrm{CH}_{2} \mathrm{~N}\right), 6.71(2 \mathrm{H}, \mathrm{d}, J 8.5$, ArH), 6.96 (1 H, dd, $J$ 1.8, 8.6, ArH), $7.03(1 \mathrm{H}, \mathrm{d}, J 2.4, \mathrm{ArH})$, 707.29 (1 H, dd, $J 1.8,8.5$, ArH), 7.37 (1 H, d, $J 1.8, \mathrm{ArH}), 7.59$ (1 $\mathrm{H}, \mathrm{s}, \mathrm{ArH}), 7.62$ (2 H, d, $J$ 9.2, ArH), $8.18(1 \mathrm{H}, \mathrm{d}, J$ 8.6, ArH) and $8.49(1 \mathrm{H}, \mathrm{d}, J$ 9.2, $\mathrm{ArH}) ; \delta_{\mathrm{C}}(75.4 \mathrm{MHz} ; \mathrm{MeOD}) 18.47$, $47.54,49.39,56.07,99.37,110.18,113.64,114.16,114.57$, $117.70,120.34,121.31,123.79,124.34,126.40,128.63,131.15$, $75133.81,135.17,151.93,155.77,156.01,158.99,159.57$ and 198.05. To $9 \mathbf{j}$ was added a solution of $\mathrm{HCl}$ saturated ether and the solution was stirred overnight to give the hydrochloride compound as a solid which was isolated by filtration, mp $251{ }^{\circ} \mathrm{C}$; $v_{\max }(\mathrm{KBr}) / \mathrm{cm}^{-1} 1620,2680$ and $3180 ; \delta_{\mathrm{H}}(300 \mathrm{MHz}, \mathrm{DMSO})$ $801.30\left(6 \mathrm{H}, \mathrm{d}, J 6.72,2 \mathrm{xCH}_{3}\right), 3.09-3.16\left(2 \mathrm{H}, \mathrm{m}, \mathrm{CH}_{2} \mathrm{~N}\right), 3.31-$ $3.60\left(5 \mathrm{H}, \mathrm{m}, 2 \mathrm{CH}_{2} \mathrm{~N}, \mathrm{CH}\right), 4.09-4.13\left(2 \mathrm{H}, \mathrm{m}, \mathrm{CH}_{2} \mathrm{~N}\right), 7.01(1 \mathrm{H}$, $\mathrm{dd}, J$ 8.5, ArH), $7.08(2 \mathrm{H}, \mathrm{d}, J$ 8.5, ArH), 7.15 (1 H, d, $J 1.8$, ArH), 7.27 (1 H, s, ArH), 7.33 (1 H, dd, $J$ 1.8, 9.2, ArH), 7.71 (2 $\mathrm{H}, \mathrm{d}, J$ 8.5, ArH), 7.79 (1 H, s, ArH), 8.37 (1 H, d, J 9.2, ArH), ${ }_{85} 8.61(1 \mathrm{H}, \mathrm{d}, J$ 9.2, ArH $), 9.84(1 \mathrm{H}, \mathrm{s}, \mathrm{OH}), 10.19(1 \mathrm{H}, \mathrm{s}, \mathrm{OH})$ and 10.58-10.67 (2 H, m, 2xNH); $\delta_{\mathrm{C}}(75.4 \mathrm{MHz}$; DMSO) 21.30 , 22.49 , 36.90, 52.38, 54.23, 98.39, 108.70, 111.50, 112.33, $112.85,115.65,118.91,119.63,122.13,122.92,125.82,129.35$, $132.61,134.43,150.10,152.67,154.70,157.48,157.69$ and 90 194.46; EIMS (m/z) $481[\mathrm{M}+\mathrm{H}]^{+}$; HPLC purity: $94.32 \%$.

3,9-Dihydroxybenzo $[b]$ naphtho[1,2- $d]$ thiophene-5-carboxylic acid 10. Nitrile $3(60 \mathrm{mg}, 0,206 \mathrm{mmol})$ was treated with a $6 \mathrm{~N}$ aqueous solution of $\mathrm{NaOH}\left(0.72 \mathrm{~g}\right.$ in $\left.3 \mathrm{~cm}^{3}\right)$ and the mixture was heated for $24 \mathrm{~h}$. After cooling, $\mathrm{HCl} 6 \mathrm{~N}$ was added and the solid 95 formed was isolated by filtration and purified by column chromatography on silica gel using DCM/MeOH 9:1 as eluent to give $10(62 \mathrm{mg}, 97 \%)$ as a white solid. $\delta_{\mathrm{H}}(300 \mathrm{MHz}, \mathrm{DMSO})$ $7.13(1 \mathrm{H}, \mathrm{d}, J$ 8.5, ArH), $7.34(1 \mathrm{H}, \mathrm{d}, J 8.5, \mathrm{ArH}), 7.49(1 \mathrm{H}, \mathrm{s}$, ArH), 8.47 (1 H, s, ArH), 8.60 (1 H, s, ArH), 8.77 (1 H, d, J 9.1, $100 \mathrm{ArH}), 8.94(1 \mathrm{H}, \mathrm{d}, J$ 9.1, $\mathrm{ArH}), 10.02(1 \mathrm{H}, \mathrm{s}, \mathrm{OH}), 10.21(1 \mathrm{H}, \mathrm{s}$, $\mathrm{OH}), 13.11(1 \mathrm{H}$, br s, $\mathrm{COOH}) ; \delta_{\mathrm{C}}(75.4 \mathrm{MHz}$; DMSO) 104.5, $107.7,108.5,115.6,118.4,120.2,122.8,126.2,127.2,129.0$, 129.2, 131.6, 132.1, 133.3, 143.3, 156.6 and 157.3; EIMS $(\mathrm{m} / \mathrm{z})$ $290[\mathrm{M}-\mathrm{H}]^{+}$

105 Methyl 3,9-dihydroxybenzo $[b]$ naphtho[1,2- $d]$ thiophene-5carboxylate 11. A solution of acid $\mathbf{1 0}(39 \mathrm{mg}, 0,126 \mathrm{mmol})$ in $\mathrm{MeOH}\left(3 \mathrm{~cm}^{3}\right)$, in presence of a catalytic amount of $\mathrm{H}_{2} \mathrm{SO}_{4}$, was heated for $24 \mathrm{~h}$. After evaporation of $\mathrm{MeOH}$ and purification by column chromatography on silica gel using DCM/MeOH 15:1 as 110 eluent, the ester 11 was obtained $(25 \mathrm{mg}, 62 \%)$ as an oil. $\delta_{\mathrm{H}}(300$ $\mathrm{MHz}, \mathrm{DMSO}) 3.95\left(3 \mathrm{H}, \mathrm{s}, \mathrm{CH}_{3}\right), 7.12(1 \mathrm{H}, \mathrm{dd}, J 9.2$ and 1.8, ArH), 7.35 (1 H, dd, $J 9.2$ and 2.4, $\mathrm{ArH}), 7.49(1 \mathrm{H}, \mathrm{d}, J 1.8$, $\operatorname{ArH}), 8.36$ (1 H, d, J 2.4, ArH), $8.62(1 \mathrm{H}, \mathrm{s}, \operatorname{ArH}), 8.78(1 \mathrm{H}, \mathrm{d}$, $J$ 9.2, $\mathrm{ArH}), 8.95(1 \mathrm{H}, \mathrm{d}, J$ 9.2, $\mathrm{ArH}), 10.07(1 \mathrm{H}, \mathrm{br} \mathrm{s}, \mathrm{OH})$ and 11510.17 (1 H, br s, OH); $\delta_{\mathrm{C}}(75.4 \mathrm{MHz}$; DMSO) 167.2, 156.8, 155.8, $143.0,132.8,131.3,131.1,127.5,126.6,126.0,125.3,123.9$, 
$122.7,118.9,115,2,109.0$ and 108.5.

\section{Computational methods}

The theoretical study of the binding mode has been carried out in 5 both subtypes of estrogen receptor, $\alpha$ and $\beta$. As macromolecules, the crystallographic structures of the two receptor subtypes in complex with several ligands have been selected: ER $\alpha$ in complex with estradiol (PDB 1A52), raloxifene (PDB 1ERR), genistein (PDB 1X7R), WAY-244 (PDB 1X7E), and 410 hydroxytamoxifen (PDB 3ERT), and ER $\beta$ in complex with genistein (PDB 1X7J), THC (PDB 1L2J), WAY-202196 (PDB 1YYE), and 4-hydroxytamoxifen (PDB 2FSZ). Water molecules close to the amino acids Arg394 (ER $\beta$ Arg346) and Glu353 (Glu305 ER $\beta$ ) have been kept for the docking procedures. ${ }_{15}$ Ligands were built using Maestro LigPrep module (www.schrodinger.com). Optimization of the geometry and the charges calculation were performed by using program Gaussian $03^{20}$ at B3LYP/3-21G* level. Once the compounds were optimized, atom types and bond types were assigned, and mol2 20 files were generated. Macromolecules geometry was refined by using Protein Preparation module in Maestro. Two different docking programs were employed in order to contrast and compare the results: AutoDock4 ${ }^{21}$ and Glide. ${ }^{22,23}$ General protocols are described as follows.

${ }_{25}$ Docking Studies with AutoDock4. Docking regions were defined considering a box of 80,80 and 90 points in the $x, y$, and $\mathrm{z}$ axes. The grids were built by focusing on the ER binding site. For the calculation of energy maps, a grid spacing of $0.375 \AA$ and a distance-dependent dielectric constant was used by means of 30 AutoGrid4. The docking was carried out using the Lamarckian genetic algorithm, leaving all the bonds as rotatable. The program searched until a maximum of 100 conformations and the procedure was repeated 100 times (runs). After docking, the 100 solutions were clustered in groups with RMSD less than $1.0 \AA$.

${ }_{35}$ For all other parameters, the default values were used with AutoDock Tools.

Docking Studies with Glide. Interaction maps of the binding site were generated using the application "Receptor grid generation", included in the Glide module, positioning the center of the box on 40 the center of the bound ligand present in the crystallographic structure. Box size was able to enclose the LBD together with helix-12, and was similar to the box defined with AutoDock. The docking procedure was performed with XP (extra precision) mode and a van der Waals radii scale factor of 1.0/0.8 for 45 receptor and ligand, respectively. Induced Fit Docking was also used, and contained constrained minimization of the receptor with an RMSD cutoff of $0.18 \AA$, and Prime-side-chain prediction on residues within a $5 \AA$ of any ligand pose. Glide redocking was performed into structures within $30 \mathrm{kcal} \mathrm{mol}^{-1}$ of the lowest 50 energy structure with van der Waals scaling of 1.0/0.8 for receptor and ligand, respectively.

Molecular Dynamics Simulations. Protein-ligand system was first minimized in vacuum for 1000 steps of steepest descent followed by 4000 steps of conjugate gradient using Amber11 ${ }_{55}$ program. $^{24}$ All $\mathrm{C} \alpha$ atoms were restrained to their initial coordinates. The resulting minimized complex was solvated by a box of TIP3P waters which extended at least $8 \AA$ away from any given protein atom. The SHAKE algorithm was applied to all hydrogen-containing bonds ${ }^{25}$ and a 1 fs integration step was used. ${ }_{60}$ The simulation used periodic boundary conditions, and the electrostatic interactions were represented using the smooth particle mesh Ewald method, ${ }^{26}$ with a grid spacing of $1 \AA$. Each system was gently annealed from 100 to $300 \mathrm{~K}$ over a period of $25 \mathrm{ps}$. The systems were then maintained at a temperature of 300 ${ }_{65} \mathrm{~K}$ during $50 \mathrm{ps}$ with positional restraints ( $\alpha$-carbon atoms), together with a distance restraint to the hydrogen bond between the Asp303 carboxylate and the piperidium NH group, and progressive energy minimizations, gradually releasing the restraints of the solute followed by a 20 ps heating phase from 70100 to $300 \mathrm{~K}$, where after restraints were removed. Finally, two production simulations were continued. The first one maintained the distance restraint between the Asp303 carboxylate and the piperidinium NH during 500 ps, plus one additional nanosecond without restriction. The second one continued the MD simulation 75 during 2 ns with no restriction. Coordinate trajectories were recorded each 2 ps throughout all equilibration and production runs (RMSD, Electronic Supplementary Information)

\section{Biological Assays}

${ }_{80}$ Chemicals. 17- $\beta$-estradiol, neutral red, dextran coated charcoal, PSB, Tween-20, BSA, ICI 180.780, 4-hydroxytamoxifen, insulin were purchased form Sigma -Aldrich. Estradiol [2,4,6,7,16,17$3 \mathrm{H}(\mathrm{N})$ ], scintillation counting liquid (Optifase HiSafe2) were obtained from Perkin-Elmer, Salem, MA). Estrogen receptors $\alpha$ ${ }_{85}$ and $\beta$ produced in insect cells and sodium pyruvate were purchased from Invitrogen. Cell culture medium DMEM, EMEM, FBS, antibiotics, trypsin-EDTA, amino acids, Lglutamine were purchased from Lonza. DCC-FBS was obtained from Hyclone (Erembodegem, Aalst, Belgium).

${ }_{90}$ Receptor Binding Studies: In vitro Competitive Binding Assay. The relative binding affinity (RBA) of the compounds for the estrogen receptors was determined by a competition assay, according to the method described by Arcaro with some modifications. ${ }^{19}$ Purified full-length human estrogen receptors $\alpha$ 95 and $\beta$ were incubated for $4 \mathrm{~h}$ at $23{ }^{\circ} \mathrm{C}$ with different concentrations of compounds in the presence of $5 \mathrm{nM}$ $[2,4,6,7,16,17-3 \mathrm{H}]$-estradiol in $150 \mu \mathrm{l}$ of total volume. The stocks of test compounds were prepared in DMSO. All these compounds, including $[2,4,6,7,16,17-3 \mathrm{H}]$-estradiol and receptors 100 were diluted in Tween $\backslash$ PBS buffer $(99,85: 0,15 \mathrm{w} / \mathrm{v})$. A vehicle control contained $0.1 \%$ of DMSO. After incubation, the nonbound $[2,4,6,7,16,17-3 \mathrm{H}]$-estradiol was removed by adding a mixture of $10 \%$ DCC and $2 \%$ albumin bovine serum, incubating $15 \mathrm{~min}$ at $4{ }^{\circ} \mathrm{C}$, followed by centrifugation at $6000 \mathrm{~g}$ for $5 \mathrm{~min}$ at $1054{ }^{\circ} \mathrm{C} .150 \mu \mathrm{l}$ of supernatant was added to $4 \mathrm{~cm}^{3}$ of scintillation liquid and the radioactivity of bound estradiol was measured in a liquid scintillation counter Beckman LS 6500 (Beckman Coulter, Inc.). Three independent experiments with three repetitions for each compound were performed. Results were expressed as the 110 percentage of specific binding of $[2,4,6,7,16,17-3 \mathrm{H}]$-estradiol to ER versus log of competitor concentration. Graph Pad Prism software (non-linear regression analysis) was used to calculate the concentration needed to displace $50 \%$ of $[2,4,6,7,16,17-3 \mathrm{H}]$ estradiol $\left(\mathrm{IC}_{50}\right)$. To compare binding affinities of the test 15 compounds to those reported in literature, $\mathrm{IC}_{50}$ values were converted to RBA values using estradiol as a standard. The 
values of $\mathrm{IC}_{50}$ for estradiol were 8,98 and $6,87 \mathrm{nM}$ for $\mathrm{ER} \alpha$ and ER $\beta$, respectively. The RBA of estradiol was arbitrarily set at 100 $\left(\mathrm{RBA}=\left(\mathrm{IC}_{50}\right.\right.$ of $\left.\mathrm{E}_{2}\right) / \mathrm{IC}_{50}$ of ligand $\left.\mathrm{x} 100\right)$.

Estrogenic and Antiestrogenic Activities. MCF-7 cells were 5 seeded in 96-well plates at $5 * 10^{3}$ cells/well in DMEM containing $10 \%$ FBS, $0,01 \mathrm{mg} / \mathrm{cm}^{3}$ of insulin solution and $0,1 \mathrm{mM}$ nonessential amino acids. After 24 hours, the medium was changed to EMEM without phenol red, containing 5\% dextrancoated charcoal stripped FBS (DCC-FBS), $0,1 \mathrm{mM}$ nonessential

10 amino acids, $1 \mathrm{mM}$ sodium pyruvate and $2 \mathrm{mM}$ L-glutamine and was preincubated for 3 days prior to treatment. Afterwards, different concentrations of the test compounds $(0,1-20 \mu \mathrm{M})$ were added to the cells with/without $1 \mathrm{pM}$ estradiol, in order to test the capacity to induce or prevent the proliferation of MCF-7 cells.

15 The final vehicle concentration of maximally $0.1 \%$ of DMSO (and $0.1 \%$ of ethanol in case of treatment with estradiol) served as a solvent control. On day 4, the medium in the plates containing the compounds was refreshed. On day 8 , cell proliferation was determined by Neutral Red uptake assay, which 20 provides a quantitative estimation of the number of viable cells. Briefly, the medium was removed and $200 \mu \mathrm{l}$ of neutral red solution $\left(50 \mu \mathrm{g} / \mathrm{cm}^{3}\right)$ was added, and incubated for $2 \mathrm{~h}$. Afterwards, the cultures were carefully washed twice with PBS, and the extraction solution was added $(250 \mu \mathrm{L}$ of $1 \%$ acetic acid, ${ }_{25} 50 \%$ ethanol), and incubated $15 \mathrm{~min}$ at room temperature. The absorbance was measured at $540 \mathrm{~nm}$ wavelength in a plate reader (Biotec). The viability was calculated considering the controls without test substance as $100 \%$ viable.

Agonist/Antagonist Profile. Reporter cells were dispensed in a 30 96-well plate and then immediately dosed with the test compounds. Following overnight incubation, the treatment media were discarded and the luciferase detection reagent was added. The intensity of light emission from the ensuing luciferase reaction provides a measure that is directly proportional to the

35 level of ER activation in the reporter cells. The assays were configured to perform agonist and antagonist dose-response curves. In order to obtain agonist dose-response curves, ER reporter cells were treated with media alone (estradiol was used as a positive control agonist). To perform receptor inhibition 40 studies a co-mix of a known agonist (estradiol: 150 and $111 \mathrm{pM}$ corresponding to $\sim \mathrm{EC}_{70}$ for $\mathrm{ER} \alpha$ and $\mathrm{ER} \beta$ assay, respectively) and a dilution series of the test compounds was prepared. IC182 780 was used as an antagonist positive control. The final solvent

\section{${ }_{85}$ References}

1. S. Nilsson and J. A. Gustafsson, Clin. Pharmacol. Ther., 2011, 89, 44-55.

2. J. A. Katzenellenbogen, R. Muthyala and B. S. Katzenellenbogen, Pure Appl. Chem., 2003, 75, 2397-2403.

90 3. S. Nilsson, K. F. Koehler and J. A. Gustafsson, Nat. Rev. Drug Discov., 2011, 10, 778-792.

4. F. Minutolo, M. Macchia, B. S. Katzenellenbogen and J. A Katzenellenbogen, Med. Res. Rev., 2011, 31, 364-442.

5. H. A. Harris, J. A. Katzenellenbogen and B. S. Katzenellenbogen, 95 Endocrinology, 2002, 143, 4172-4177.

6. H. A. Harris, L. M. Albert, Y. Leathurby, M. S. Malamas, R. E. Mewshaw, C. P. Miller, Y. P. Kharode, J. Marzolf, B. S. control didn't exceed $0.1 \%$ of DMSO. All measurements were ${ }_{45}$ performed in triplicate.

\section{Abbreviations}

Abbreviations: BSC, basic side chain; PDB, Protein Data Bank; DCM, dichloromethane; THF, tetrahydrofuran; DMF, dimethylformamide; RT, room temperature; $\mathrm{MD}$, molecular 50 dynamics; RMSD, root-mean-square deviation; RBA, Relative Binding Affinity.

\section{Acknowledgements}

This work was supported by the Spanish Ministry of Science and Innovation (SAF2008-00945, CTQ2011-24741 and ${ }_{55}$ CSD2007-00063) and Fundación Universitaria San Pablo CEU (USP-PC 13/10). Grants to J. J. R. from Fundación Universitaria San Pablo CEU is also acknowledged. We thank EADS-CASA for fellowships to K. F., M. M., J. C. and S. D.

\section{${ }_{60}$ Notes}

${ }^{a}$ Departamento de Química, Facultad de Farmacia, Universidad CEU San Pablo, 28668-Boadilla del Monte, Madrid, Spain. Fax: (+34)913510496; Tel: (+34)913724796; E-mail: aramgon@ceu.es; smsantamaria@ceu.es.

$65{ }^{b}$ Department of Molecular Biology, Faculty of Mathematics and Natural Sciences, The John Paul II Catholic University of Lublin, 20-718 Lublin, Poland.

${ }^{c}$ Department of Environmental Biochemistry and Chemistry, Faculty of Mathematics and Natural Sciences, The John Paul II Catholic University 70 of Lublin, 20-718 Lublin, Poland.

${ }^{d}$ Department of Organic Chemistry, Gdansk University of Technology, 11/12 G. Narutowicza St., 80-233 Gdańsk, Poland.

e Institute of Food Science, Food Technology and Nutrition (ICTAN), Spanish National Research Council (CSIC), José Antonio Novais 10, 75 28040-Madrid, Spain.

$\dagger$ Electronic Supplementary Information (ESI) available: $\delta_{\mathrm{H}}$ and $\delta_{\mathrm{C}}$ NMR spectra of compounds $\mathbf{5 b}, \mathbf{6 b}, \mathbf{7 b}, \mathbf{8 a - j}, \mathbf{9 a - j}, 10$ and 11. Data from docking calculations and MD simulations.

Komm, R. C. Winneker, D. E. Frail, R. A. Henderson, Y. Zhu and J. C. Keith, Endocrinology, 2003, 144, 4241-4249.

100 7. M. J. Meyers, J. Sun, K. E. Carlson, G. A. Marriner, B. S. Katzenellenbogen and J. A. Katzenellenbogen, J. Med. Chem., 2001, 44, 4230-4251.

8. R. E. Mewshaw, J. Edsall, Richard J., C. Yang, E. S. Manas, Z. B. $\mathrm{Xu}, \mathrm{R}$. A. Henderson, J. C. Keith Jr. and H. A. Harris, J. Med. Chem., 2005, 48, 3953-3979.

9. E. S. Manas, R. J. Unwalla, Z. B. Xu, M. S. Malamas, C. P. Miller, H. A. Harris, C. Hsiao, T. Akopian, W.-T. Hum, K. Malakian, S. Wolfrom, A. Bapat, R. A. Bhat, M. L. Stahl, W. S. Somers and J. C. Alvarez, J. Am. Chem. Soc., 2004, 126, 15106 15119.

10. M. De Angelis, F. Stossi, K. A. Carlson, B. S. Katzenellenbogen and J. A. Katzenellenbogen, J. Med. Chem., 2005, 48, 1132-1144. 
11. J. Sun, M. J. Meyers, B. E. Fink, R. Rajendran, J. A. Katzenellenbogen and B. S. Katzenellenbogen, Endocrinology, 1999, 140, 800-804.

12. M. J. Meyers, J. Sun, K. E. Carlson, B. S. Katzenellenbogen and J. A. Katzenellenbogen, J. Med. Chem., 1999, 42, 2456-2468.

13. A. M. Brzozowski, A. C. W. Pike, Z. Dauter, R. E. Hubbard, T. Bonn, O. Engström, L. Öhman, G. L. Greene, J. A. Gustafsson and M. Carlquist, Nature, 1997, 389, 753-758.

14. A. K. Shiau, D. Barstad, J. T. Radek, M. J. Meyers, K. W. Nettles, B.

10 S. Katzenellenbogen, J. A. Katzenellenbogen, D. A. Agard and G. L. Green, Nat. Struct. Biol., 2002, 9, 359-364.

15. B. R. Henke, T. G. Consler, N. Go, R. L. Hale, D. R. Hohman, S. A. Jones, A. T. Lu, L. B. Moore, J. T. Moore, L. A. OrbandMiller, R. G. Graham Robinett, J. Shearin, P. K. Spearing, E. L. Stewart, P. S. Turnbull, S. L. Weaver, S. P. Williams, G. B. Wisely and M. H. Lambert, J. Med. Chem., 2002, 45, 54925505.

16. J. Shen, C. F. Tan, Y. Y. Zhang, X. Li, W. H. Li, J. Huang, X. Shen and Y. Tang, J. Med. Chem., 2010, 53, 5361-5365.

20 17. S. Martín-Santamaría, J. J. Rodríguez, S. de Pascual-Teresa, S. Gordon, M. Bengtsson, I. Garrido-Laguna, B. Rubio-Viqueira, P. P. López-Casas, M. Hidalgo, B. de Pascual-Teresa and A. Ramos, Org. Biomol. Chem., 2008, 6, 3486-3496.

18. A. M. Ramos, J. J. Rodríguez, S. Martín-Santamaría, B. de Pascual25 Teresa , M. Hidalgo, P. P. López-Casas and B. RubioViqueira, in España, Patente de Invención ES P200801961, 2008.

19. K. F. Arcaro, Y. Yang, D. D. Vakharia and J. F. Gierthy, J. Toxicol. Environ. Health A, 2000, 59, 197-210.

30 20. M. J. Frisch, G. W. Trucks, H. B. Schlegel, G. E. Scuseria, M. A. Robb, J. R. Cheeseman, J. Montgomery, J. A., T. Vreven, K. N. Kudin, J. C. Burant, J. M. Millam, S. S. Iyengar, J. Tomasi, V. Barone, B. Mennucci, M. Cossi, G. Scalmani, N. Rega, G. A. Petersson, H. Nakatsuji, M. Hada, M. Ehara, K. Toyota, R. Fukuda, J. Hasegawa, M. Ishida, T. Nakajima, Y. Honda, O. Kitao, H. Nakai, M. Klene, X. Li, J. E. Knox, H. P. Hratchian, J. B. Cross, V. Bakken, C. Adamo, J. Jaramillo, R. Gomperts, R. E. Stratmann, O. Yazyev, A. J. Austin, R. Cammi, C. Pomelli, J. W. Ochterski, P. Y. Ayala, K. Morokuma, G. A. Voth, P. Salvador, J. J. Dannenberg, V. G. Zakrzewski, S. Dapprich, A. D. Daniels, M. C. Strain, O. Farkas, D. K. Malick, A. D. Rabuck, K. Raghavachari, J. B. Foresman, J. V. Ortiz, Q. Cui, A. G. Baboul, S. Clifford, J. Cioslowski, B. B. Stefanov, G. Liu, A. Liashenko, P. Piskorz, I. Komaromi, R.

45 L. Martin, D. J. Fox, T. Keith, M. A. Al-Laham, C. Y. Peng, A. Nanayakkara, M. Challacombe, P. M. W. Gill, B. Johnson, W. Chen, M. W. Wong, C. Gonzalez and J. A. Pople, Gaussian 03, Revision C.02, Gaussian, Inc., (2004), Wallingford CT.

50 21. R. Huey, G. M. Morris, A. J. Olson and D. S. Goodsell, J. Comp. Chem., 2007, 28, 1145-1152.

22. R. A. Friesner, J. L. Banks, R. B. Murphy, T. A. Halgren, J. J. Klicic, D. T. Mainz, M. P. Repasky, E. H. Knoll, M. Shelley, J. K. Perry, D. E. Shaw, P. Francis and P. S. Shenkin, J. Med.
23. T. A. Halgren, R. B. Murphy, R. A. Friesner, H. S. Beard, L. L. Frye, W. T. Pollard and J. L. Banks, J. Med. Chem., 2004, 47, 17501759.

24. D. A. Case, T. A. Darden, T. E. Cheatham III, C. L. Simmerling, J. 60 Wang, R. E. Duke, R. Luo, R. C. Walker, W. Zhang, K. M. Merz, B. Roberts, B. Wang, S. Hayik, A. Roitberg, G. Seabra, I. Kolossváry, K. F. Wong, F. Paesani, J. Vanicek, J. Liu, X. Wu, S. R. Brozell, T. Steinbrecher, H. Gohlke, Q. Cai, X. Ye, J. Wang, M.-J. Hsieh, G. Cui, D. R. Roe, D. H. Mathews, M. G. Seetin, C. Sagui, V. Babin, T. Luchko, S. Gusarov, A. Kovalenko and P. A. Kollman, AMBER 11, University of California, San Francisco., 2010.

25. J. P. Ryckaert, G. Ciccotti and H. J. C. Berendsen, J. Comput. Phys., 1977, 23, 327-341.

70 26. T. Darden, D. York and L. Pedersen, J. Chem. Phys., 1993, 98, 10089-10092. 